\title{
Chapter 6 \\ The Visibility of the Romana Ecclesia: Cesare Baronio and the Evidence of the Invisible
}

\author{
Filip Malesevic
}

\begin{abstract}
With the discovery of the tombs of the first early Christian martyrs in 1578 , the papacy and the curia could not only sustain their claims for the primacy of Rome in theological matters based on the fact that it was the primary place of early Christian martyrdom, but now it became possible to support this claim with visual evidence. This evidentiary character of early Christian Martyrdom had significant consequences for the adoption and interpretation of the Roman liturgy, especially the veneration of saints that the Protestants so vehemently attempted to deny. This chapter explores the influence of this discovery in general but also in the context of an emergent scientific discourse at the Roman curia about celestial phenomena that received new impetus after the observation of a series of comets around the Jubilee Year of 1575, the interpretation of which would influence the pope's decision to reform the Julian calendar. This reform would furthermore be adopted by the Oratorian-and later Cardinal-elect-Cesare Baronio who was commissioned to provide corrections for a new edition of the Martyrologium Romanum. The chapter suggests a far larger interrelationship between Baronio's work on the Martyrologium and the discourse around the correct interpretation of celestial phenomena by Roman curialists. Additionally, it suggests an important influence on Baronio's Martyrologium by some major iconographic programs developed in the Vatican Apostolic Palace at the time of Gregory XIII's papacy.
\end{abstract}

\subsection{Introduction}

In the holy year of 1575 , the Bolognese physician and philosopher Baldassare Pisanelli penned a tract entitled Discorso sopra il dragone di fuoco (Discourse on the dragon of fire). This work was an attempt to explain the significance of the fiery

\footnotetext{
F. Malesevic $(\square)$

University of Fribourg, Fribourg, Switzerland

e-mail: filip.malesevic@unifr.ch
} 
Fig. 6.1 Heraldic Emblem of Pope Gregory XIII. From Francesco Ceccarelli and Nadja Aksamija. La Sala Bologna nei Palazzi Vaticani: Architettura, cartografia e potere nell'età di Gregorio XIII (Venice, 2011), 32, fig. 11. (Cappella Gregoriana, San Pietro, Vaticano)

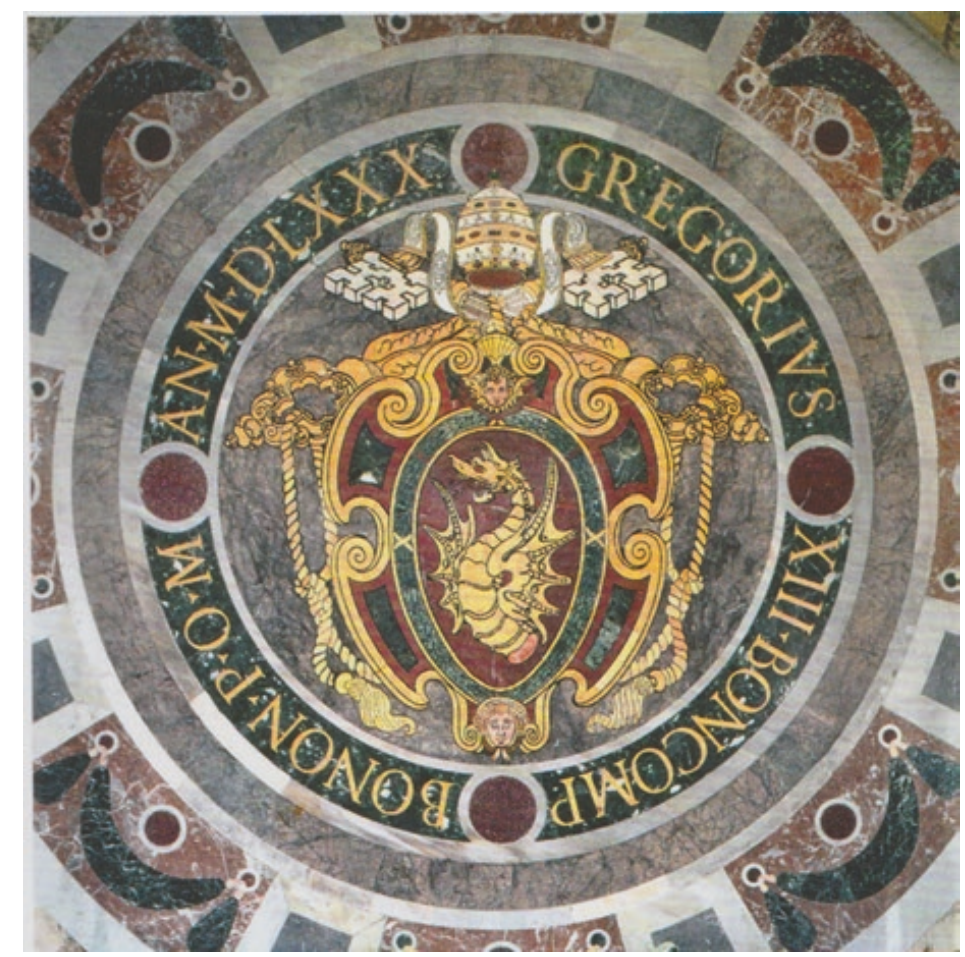

dragon that had recently been seen in the skies above the city of Rome. Although this was most likely nothing more than the trail of a comet as it passed close to the earth's atmosphere, in Milan where it was identified as the gran colubro (great snake) and linked to the Visconti family whose crest depicted a viper, it was deemed to have caused the plague that had broken out across much of the peninsula that year.

For Pisanelli, though, such a straightforward causative connection between celestial event and terrestrial misfortune was problematic, for the emblem of Ugo Boncompagni-now pope Gregory XIII-was a dragon. The Boncompagni were descendants of the Dragoni family which traced its origins to Assisi. However, when the family migrated north to Bologna, the name mutated into Boncompagni. Despite this, the family kept the dragon as its emblem, for by this point it was part of the family's history and identity. ${ }^{1}$ In itself, the image of a dragon on a pope's emblem might have been problematic, but it was clear from the gloss on the Boncompagni emblem that the pope's dragon was intended to be interpreted through the lens of Revelations 12:9, "And the great dragon was thrown down, that ancient serpent, who is called the devil and Satan, the deceiver of the whole world-he was thrown down to the earth, and his angels were thrown down with him," as the dragon of the apocalypse (Fig. 6.1).

\footnotetext{
${ }^{1}$ See Eugenio Gamurrini, Discorso genealogico della famiglia Dragona Buoncompagna (Foligno, 1662) as quoted in Paolo Francesco Boncompagni Ludovisi, "La famiglia Boncompagni: tra Bologna e Roma," in Incunaboli e cinquecentine della biblioteca di Gregorio XIII Boncompagni: Dal Collegio Germanico alla Pontificia Università Lateranense, ed. Luigi Falcone (Vatican City, 1998), 14-18. For the Boncompagni papacy still useful the accounts in Ludwig Freiherr von Pastor, The History of the Popes from the Close of the Middle Ages, vol. 19 (London, 1930).
} 
This was decidedly awkward, for Protestants had long portrayed the papacy as the embodiment of the Antichrist to great rhetorical advantage. ${ }^{2}$ But with the Boncompagni emblem now that of the pope, it was difficult to deny the connection between the papacy and the subjugation of the earthly urbs prophesied as part of the end times: it was evident that the multi-headed beast of the apocalypse was at the heart of the church. For Catholics, too, the sight of the fiery dragon above Rome just three years after Gregory's inauguration served only to underscore this connection. But that was not the end of the matter, for the dragon was followed two years later by the sight of a great comet, an event widely heralded by astrologers across the continent as presaging schism, heresy, war and other manifestations of divine wrath. The prophecy depicted in the pope's emblem, it seems, was being borne out in the heavens. The observation of an astrophysical event was rarely neutral. Just as those who saw it did so from different vantage points, so they assimilated it into different discursive frames, interpreting it according to the recent history of their respective cities.

The challenge for the Boncompagni pontificate, then, was to find a way to recast these natural, celestial phenomena, to convert them from mere semblances (simulacra) into proper, positive Christian images (imagines), and to forestall reading them as evidence of a connection between Gregory's pontificate and the apocalypse. In the end, this was done pictorially through the production of emblems. Emblems were frequently used to convey evidence that could be apprehended by sight, and were generally supposed to be carefully interpreted through a sophisticated, predefined visual rhetoric. As the humanist-bishop Angelo Rocca reminded his reader in his undated Discorso filosofico et teologico intorno alle comete (Philosophical and theological discourse on comets), "starting from our eyes, apart from observable things, all that remains are fantasies and ghosts." 3

The aim of this chapter is to examine how, within the topological sphere of the city of Rome and the curia, the astronomical observations of 1575 and 1577, which initially invited superstitious interpretations, were transformed into useful instruments of inquisitorial and social control. Recast in this way, these observations came to have an important and hitherto unexplored influence on the reform of liturgical books. The most important of these, of course, were the revisions to the Martyrologium Romanum (The Roman Martyrology), work which was grounded in the new calendar - and so contingent upon astronomical evidence. In this way, the desire of church authorities to assimilate the evidence of celestial events into a framework defined by the curia that endowed them with an acceptable signification is analogous to their endeavors to articulate a teleology for the evolution of the

\footnotetext{
${ }^{2}$ The literature here is immense. But see, for instance, Robert W. Scribner, For the Sake of the Folk: Popular Propaganda for the German Reformation (Cambridge, 1981) and Tessa Watt, Cheap Print and Popular Piety 1550-1564 (Cambridge, 1991) for a couple of examples.

${ }^{3}$ As quoted in Marco Ruffini, "Un drago per il papa: Emblematica e politica alla corte di Gregorio XIII," in Unità e fammenti di modernità: Arte e scienza nella Roma di Gregorio XIII Boncompagni (1572-1585), ed. Claudia Cieri Via, Ingrid D. Rowland, Marco Ruffini (Pisa/Rome, 2012), 122.
} 
papacy — and the Roman church as a whole — from late antiquity that was both historically legitimate and acceptable.

However, 1578 also saw the rediscovery of the tombs of the early Christian martyrs on the Via Salaria Nuova-tangible, evocative evidence not just of the persecutions of late Antiquity, but of the subterranean dimension to the church during this formative period. As one commentator noted in August of that year:

The place is so venerable by reason of its antiquity, its religion and sanctity, as to excite emotion, even to tears, in all who go there and contemplate it on the spot. There men can picture to themselves the persecutions, the sufferings and the piety of the saintly members of the primitive church, and it is obviously a further confirmation of our Catholic religion. One can now see with one's own eyes, how, in the days of the pagan idolaters, those holy and pious friends of Our Lord, when they were forbidden public assemblies, painted and worshipped their sacred images in these caves and subterranean places; those images which blinded Christians today seek, with sacrilegious zeal, to remove from the churches.

In this sense, the new evidence of the rediscovered tombs of the martyrs gave the celebration of saints' birthdays historical legitimacy.

Thus, this chapter will attempt to link that which was discovered below with that which is above. It will consider the city of Rome with its newly rediscovered subterranean topographical spaces such as the Via Salaria Nuova as a reflection of the astronomical sphere, conceiving the Romana ecclesia in the mode of St. Augustine's De civitate Dei not just as a reflection of the extra-temporal heavenly church, but with its civitas subterranea as an historical church prompting reform of the Roman rite in the present. In making this case, it will be necessary to consider some of the artistic production that helped condition such specific views about reform, and the curia's efforts to assert its primacy in matters to do with the interpretation of astrophysical phenomena. ${ }^{4}$

\footnotetext{
${ }^{4}$ The Council of Trent (1545-1563) argued that the curia's view would be sovereign in matters such as the correct interpretation of astrophysical appearances. One such instant was the ninth Tridentine decree considering the prohibition of works that wrote of divination and lot-casting, for which see esp. Franz Heinrich Reusch, Der Index der verbotenen Bücher: Ein Beitrag zur Kirchenund Literaturgeschichte, 3 vols. (Aalen, 1967), vol. 1, 338 f., as well as Ugo Baldini, "The Roman Inquisition's Condemnation of Astrology in the Sixteenth Century; Antecedents, Reasons and Consequences," in Church, Censorship and Culture in Early Modern Italy, ed. Gigliola Fragnito, 79-110 (Cambridge: Cambridge University Press, 2001), 95. Another instance was Pope Pius IV's bull Benedictus Deus from 1564 that approved the Tridentine council as an ecumenical synod of the Universal Church and declared the curia the only legitimate apparatus of interpreting its decrees. On this, see Hubert Jedin, Geschichte des Konzils von Trient, 4 vols (Freiburg i. Br., 1949-75), vol. 4/2, 226.
} 


\subsection{Pope Gregory XIII and his Dragon: Emblems as Evidence}

Through the second half of the sixteenth century, demonology was an intensely contested ideological battlefield which saw Catholic and Protestant scholars alike use their understanding of the demonic to demonize their rivals. In 1562, for instance, the editor and translator Anton Francesco Doni published a treatise which, in commenting upon Revelations 13, identified Martin Luther as the dragon heralding the coming of end times. With the election of Gregory XIII ten years later, Protestant polemicists turned Doni's comments on their head, claiming that it was the papacy that was the embodiment of the Antichrist, citing, among other things, the Boncompagni heraldic emblem of a dragon as evidence. ${ }^{5}$ Even before the 1575 celestial dragon, then, it was imperative for the pope to reconfigure the significance of the family's crest, and to downplay its obvious apocalyptic connotations.

One way this was done was by stressing the pope's relationship with his native city of Bologna. As Gregory's first biographer, Marc' Antonio Ciappi documented, the pope proved particularly paternalistic towards his home town, appointing various members of the curia to offices in the city upon his elevation. In his Delle Allusioni, Imprese, et Emblemi, the priest Principio Fabrizi endeavored to encapsulate the pope's protection and authority within the city in a number of engravings. ${ }^{6}$ Although Fabrizi's text was not published until 1588, some 3 years after the pope's death, as the author explained in a dedicatory letter to Giacomo Boncompagni, he had offered the work to the pontiff in manuscript form in 1582. Unfortunately, problems in the engraving process had necessitated a six-year delay in publication. ${ }^{7}$

Here, two incisions that deal with the pope's ties to Bologna are of particular interest. The first, entitled Bona omnia, shows a dragon flying over the city; the second, Nos mundantem dedit, shows the same creature swimming through the flowing water adjacent to the city's center. What is significant here, though, is that in the second image, the dragon does not appear as an apocalyptic omen related to the subjugation of the earthly orbem; rather, in Fabrizi's hands, the image is transformed into an emblem of protection. The dragon here stands in a close relationship with Bologna, a city already well known as a center for the natural sciences and for study of canon law. ${ }^{8}$ Although the prints in Fabrizi's book are intended to depict the

\footnotetext{
${ }^{5}$ Anton Francesco Doni, Espositione del Doni sopra del XIII cap. Dell'Apocalisse (Padua, 1562).

${ }^{6}$ Marc' Antonio Ciappi, Compendio delle heroiche et cloriose attioni et santa vita di papa Gregorio XIII (Rome, 1596), 84-95, and Principio Frabricii, Delle allusioni, imprese, et emblemi del sig. Principio Frabricii sopra la vita, opere, et attioni di Gregorio XIII, pontefice massimo ... (Rome, 1588).

${ }^{7}$ Principio Fabricii, Delle allusioni, 385.

${ }^{8}$ This is implied by the rhyme beneath the incision in Principio Fabricii, Delle allusioni, 8: "Se d' ogn bene, onde'l bel nome porta/ Quest' antica Città fu colma, e piena,/ E del' altre più chiara, e più serena,/ E ch' a' viventi ogni saper' apporta;/ Quant' hora sià più diligente, e accorta,/ Chà del fonte divin per larga vena/ Vera scienza da Colui, che frena/ Il mondo, \& è del Ciel scala, uscio, e scorta?/ Se de studi, e scienza ella fù Madre,/ Madre più saggia hor' è Regina, e Donna,/ Che diede à Noi d' ogni scienza il Padre./ Se fu di Nobiltà chiara Colonna,/ Che sostenne d'Astrea le belle squadre,/ Hora del Ciel nel suo pensier s'indonna."
} 


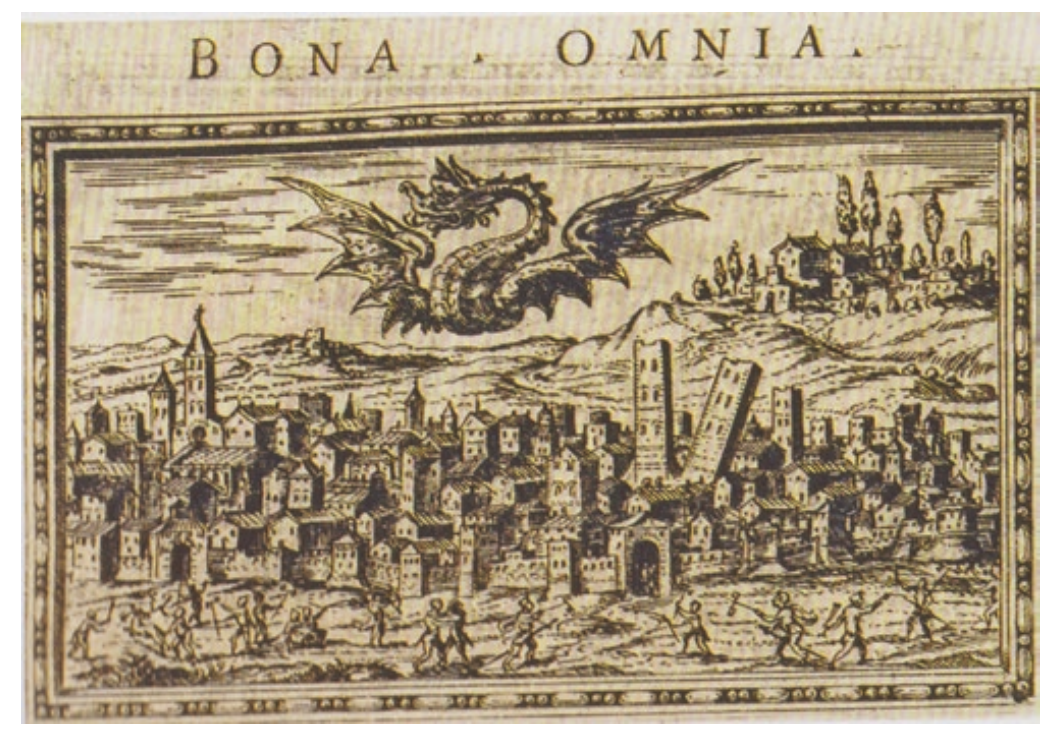

Fig. 6.2 Bona Omnia. From Principio Fabricii, Delle allusioni, imprese, et emblemi [...] (Rome, 1588), 8. From Francesco Ceccarelli and Nadja Aksamija, La Sala Bologna nei Palazzi Vaticani: Architettura, cartografia e potere nell'età di Gregorio XIII (Venice, 2011), 15, fig. 2 (Biblioteca Universitaria di Bologna)

pope guarding his native city, the interplay between papal heraldry and the importance of the urbs clearly has a particularly Roman dimension that has so far been neglected in the scholarship (Figs. 6.2 and 6.3).

A more immediate response to the anxieties associated with the pope's emblem can be found in Pisanelli's In emblemata Pontificii stemmatis coniecturae (Interpretations of the emblems of the pontifical lineage). Written in 1572 shortly after Gregory's election, here Pisanelli attempted to minimize the apocalyptic overtones of the Boncompagni dragon. As Pisanelli noted, the pope's dragon had become the subject of much lively discussion. Indeed, it comprised the focus of numerous letters, treatises, leaflets and printed manuscripts. Chief amongst these was, perhaps, the work of the naturalist Ulisse Aldrovandi who wrote to the pope's son, Giacomo Boncompagni, on the subject. For Aldrovandi, the fact that the emblem dragon ought not to be read as an apocalyptic sign was signaled by the fact that a dragon had appeared in the Bolognese countryside on 13 May 1572-the very day Boncompagni returned to the city to be invested as pope.

Three years later, Pisanelli turned his attention to the 1575 "dragon of fire" in his Discorso sopra il dragone di fuoco (Discourse on the dragon of fire). The association of comets - or celestial dragons — with the plague was common. Indeed, dragon and plague were often construed in a cause-effect relationship by astrologers, a fact apparently confirmed by the outbreak of the plague in Milan and Venice that year and in Padua the next. But what Pisanelli did in this treatise was to show that the astral phenomenon was actually an effect caused by nature. ${ }^{9}$ But he goes further, for he also draws a clear distinction between this particular natural phenomenon,

\footnotetext{
${ }^{9}$ Baldassare Pisanelli, Discorso sopra il dragone di fuoco apparso in Roma, l'anno 1575 (Bologna, 1575).
} 
Fig. 6.3 Nos Mundatem Dedit. From From Principio Fabricii, Delle allusioni, imprese, et emblemi [...] (Rome, 1588), 9. From Francesco Ceccarelli and Nadja Aksamija, La Sala Bologna nei Palazzi Vaticani: Architettura, cartografia e potere nell'età di Gregorio XIII (Venice, 2011), 15, fig. 3 (Biblioteca Universitaria di Bologna)

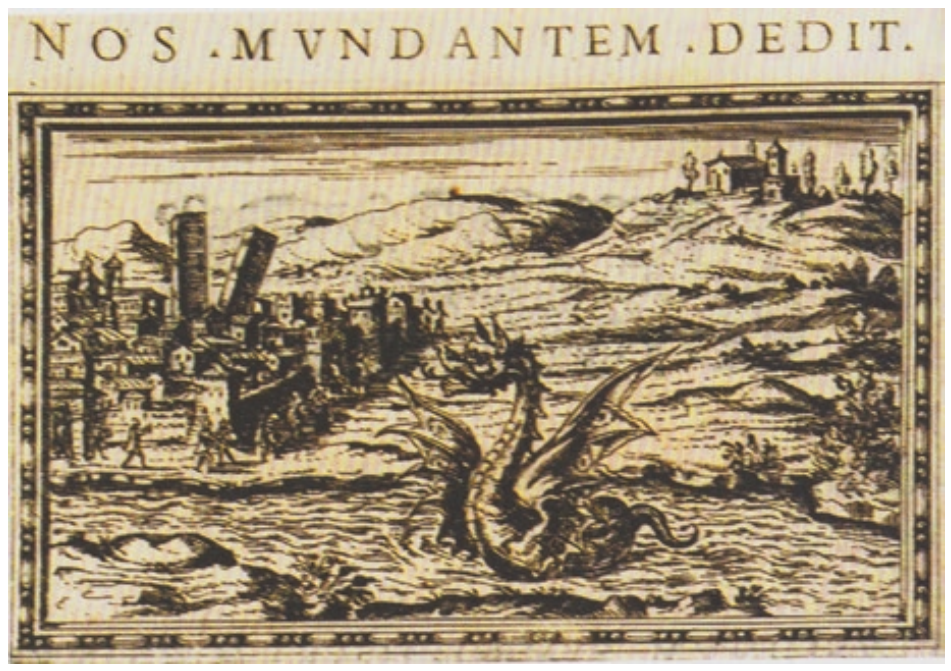

comets in general, and the disastrous spread of the plague, which would spread in Northern Italy a year later. Indeed, Pisanelli continues, the fact that the celestial dragon was a natural effect and not an ominous omen was further underscored by various astrologers at Gregory's court, for they had predicted just such a comet appearing in the constellation of Gemini that year. ${ }^{10}$

A year later, between 8 November 1576 and 6 January 1577, the great comet famously studied by Tycho Brahe was observed above Rome. In Italy, though, the sighting led to Angelo Rocca's Discorso filosofico et teologico. What Pisanelli and Rocca's treatises have in common is their rejection of astrologia iudiciaria (that is, judicial astrology) and the Ptolemaic dictum sapiens dominabitur astris (humans are dominated by the stars), arguing instead that comets are natural occurrences. Thus, Rocca follows Pisanelli in distinguishing comets from other atmospheric impressioni, especially the serpenti infuocati:

Nevertheless, in order to understand better one should know that not all the advancements take place in the air region above, like the fiery serpents ... the jumping goats, the flying stars or the shooting ones which fall down transversally and violently since by nature they tend to go upwards the effects of which all arise in the first region in the air near us. ${ }^{11}$

Not only does this passage testify to a strong interdependence between Rocca's and Pisanelli's defense against the superstitious beliefs fostered by astrologers, but it was likely influenced by Christoph Clavius' commentary on Johannes de Sacrobosco's De sphaera mundi in which the Jesuit mathematician distinguished

\footnotetext{
${ }^{10}$ Pisanelli, Discorso, cc. 2-2v. See also Marco Ruffini, Le imprese del drago: Poilitica, emblematica e scienze naturali alla corte di Gregorio XIII (1572-1585) (Rome, 2005), 66.

${ }^{11}$ Ruffini, Le imprese del drago, 70: “[...] nondimeno per maggiore intelligenza è da sapere che non tutte le essaltationi son fatte nella di sopra regione dell' aria, come gl' infuocati serpenti, [...] le capre saltanti, le stelle volatili, o cascanti traversalmente cadendo in giù elle di moto violento per esser di natura ascendenti, i quali effetti si generano tutti nella prima regione dell' aria vicina a noi.” English translations, unless otherwise indicated, have been provided by the author.
} 
astrology from astronomy. ${ }^{12}$ This distinction between the appearance of natural phenomena and their interpretation relative to the state of the papal court strengthened the idea that comets would produce negative effects in heretical territories such as the Protestant parts of the Empire, for these were not territories governed by the Holy See, as Pisanelli also affirmed in his 1582 Discorso. ${ }^{13}$

In fact, this attack on superstitious belief, enabled by the attack on astronomia iudiciaria, is fully realized in an engraving by Filippo Sega from 1574, in preparation for the 1575 Holy Year. This shows Rome as a garden in which visiting pilgrims can pick the fruits of indulgence under the protection of Gregory XIII's heraldic dragon, which here clearly is intended as a symbol of prudence and security. This image also conforms to the language used by Rocca, Pisanelli and even Aldrovandi to characterize natural phenomena. For them, the representations of comets were not proper imagines but simulacra; they were things that the eye might observe in nature and which could be preserved in illustrations. According to the Jesuit Claude Menestrier, no image could depict visible reality properly. But images could be signifiers of reality - things he dubbed "knowing images" (immagines conoscibiles). For Menestrier, such images were true carriers of emblematic significance. Aldrovandi expressed a similar notion when writing about naturalistic illustrations. For him, such "figures appear as proper simulacra of nature itself, which widen the beholder's eyes." 14 In this sense, only the Romana Ecclesia could lay claim to subsisting at the level of imago, for only it was a true image of transcendent reality (Figs. 6.4 and 6.5).

Significantly, this meant that during Gregory XIII's pontificate the measures taken against superstitious observations under the Tridentine rules dealing with the prohibition of heretical books were sophisticatedly converted into iconographic promoters of Christian piety and works of mercy. Emblems, then, were an epistemologically secure mode of accurate depiction which conformed to appropriate devotional attitudes, and a mode clearly distinct from mere pictures, for they led to superstition and were, therefore, deemed heretical. ${ }^{15}$

\footnotetext{
${ }^{12}$ Christoph Clavius, In Sphaeram Ioannis de Sacro Bosco commentarius (Venice, 1601), 5.

${ }^{13}$ Baldassare Pisanelli, Discorso sopra la cometa che apparve in Roma alli XI maggio 1582 (Bologna, 1582), c. 4v. See Maro Ruffini, Le imprese del drago, 72.

${ }^{14}$ See Claude Francois Menestrier, L'art des emblêmes (Lyon, 1662), 4; Christian Jouhaud, "Readability and Persuasion: Political Handpills," in The Culture of Print: Power and Uses of Print in Early Modern Europe, ed. Roger Chartier (Princeton 1987), 235-260. The quotation is from Olmi, L'inventario del mondo, 67.

${ }^{15}$ M. Praz, "Il concetto di emblematica e le sue manifestazioni nel Rinascimento e nell' età barocca," Emblemi e Insegne, 4 (1971): 794-799. The Jesuits also played a significant role in this process of defining the appropriateness of pictures. See Gauvin Alexander Bailey, Between Renaissance and Baroque: Jesuit Art in Rome, 1565-1610 (Toronto: University of Toronto Press, 2009), 81-82.
} 


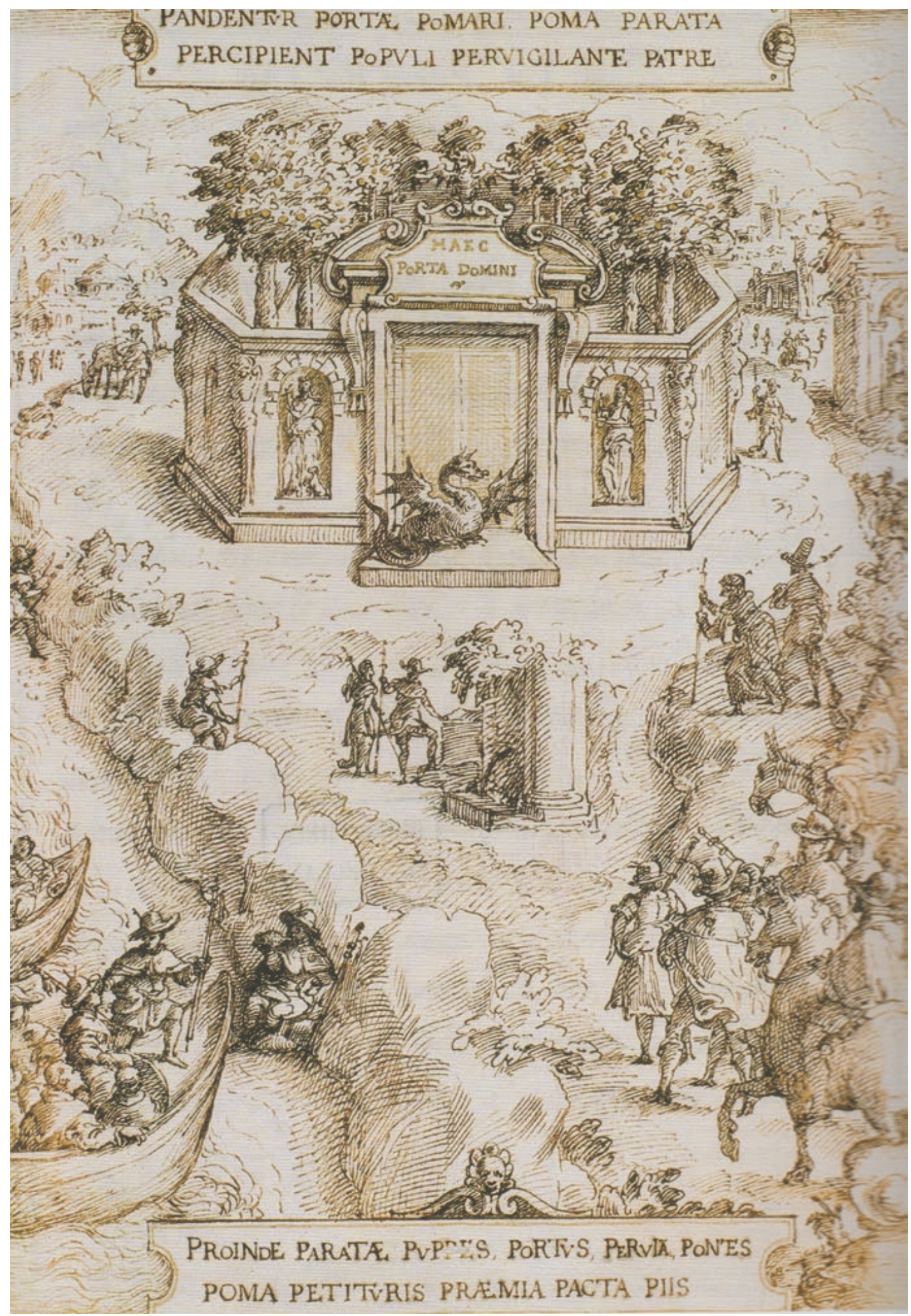

Fig. 6.4 Filippo Sega, Agevole sentiero per l'anno santo all' Illustriss(im)o et r(everendissi)mo mons(ign)or il Cardinal Guastavillani, Ms. vall. G 34, Biblioteca Vallicelliana, Rome 


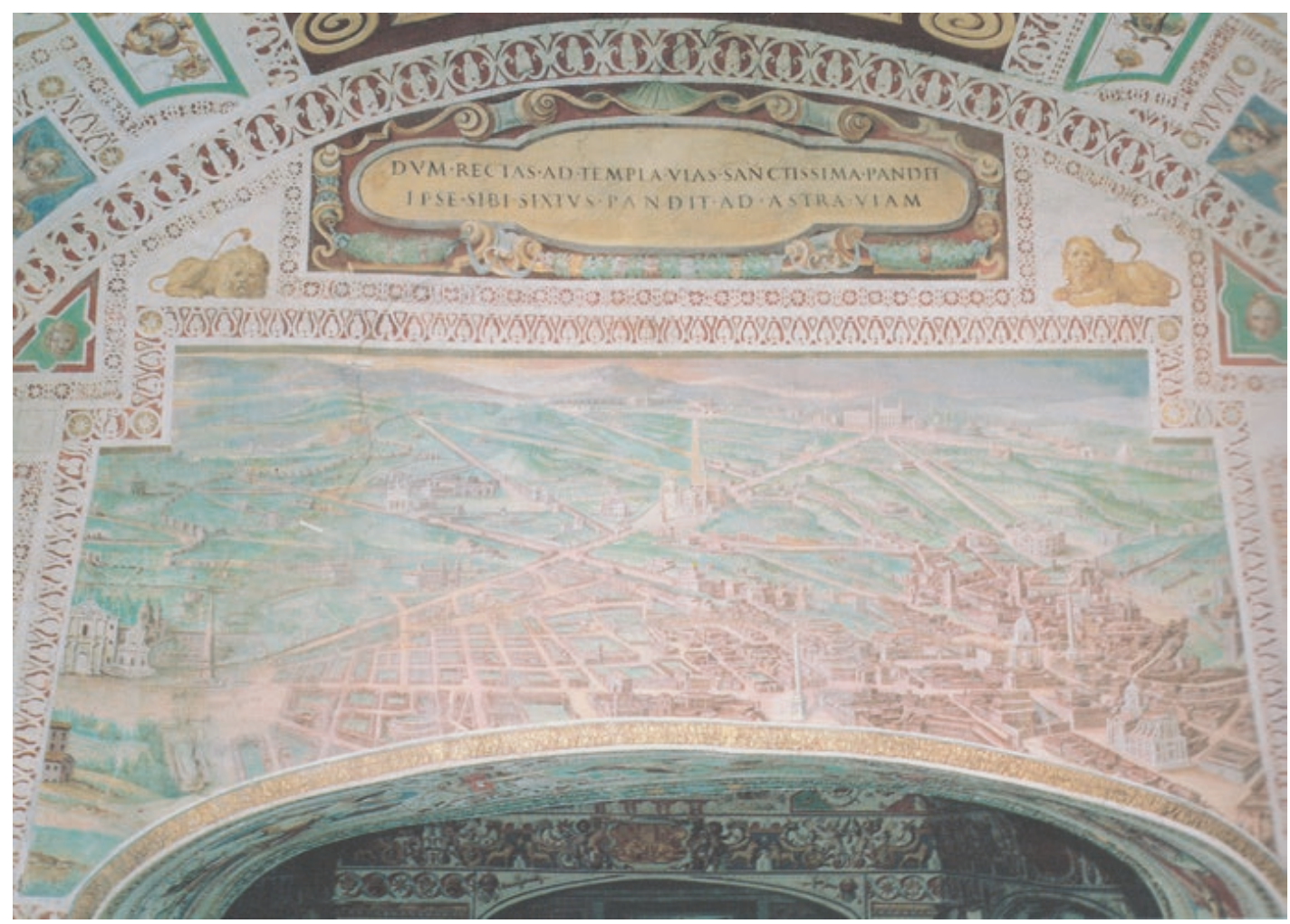

Fig. 6.5 Cesare Nebbia and Giovanni Guerra, Panoramic View of Sistine Rome, 1587-89. From Thomas M. Lucas, S.J., ed., Saint, Site, and Sacred Strategy: Ignatius, Rome, and Jesuit Urbanism, catalogue of the exhibition (Vatican City, 1990), 42. (Salone Sistino, Biblioteca Apostolica Vaticana, Vaticano)

\subsection{Reform as a Rite of Passage in the Vatican Apostolic Palace}

The transformation of the Roman curia from the middle of the sixteenth century is visually exemplified in the process of urban renewal across the city championed by successive popes at about the same time. Under Gregory, the number and scale of building projects championed by the papacy increased enormously. Among these was the plan to build a network of straight roads connecting Rome's seven major basilicas, highlighting the city's most important locations for pious devotion. Gregory began with the construction of the Via Gregoriana (now Via Merulana) which connected the basilicas of S. Giovanni in Laterano and S. Maria Maggiore. While it was left to Sixtus V, Gregory's successor, to finish this work, the effect was to sacralize the urban geography of the city itself. This new web of roads allowed pilgrims to visit Rome's major basilicas with ease, purging themselves of sin as they moved through the city space. It transformed Rome into a more modern città sancta. ${ }^{16}$

\footnotetext{
${ }^{16}$ For Gregory XIII's urban projects, see esp. M. Fagiolo and M. Luisa Madonna, "La Roma di Pio IV: La Civitas Pia, la Salus Medica, la Custodia Angelica, Parte I: il programma," Arte illustrata
} 
The visual effect of this project is encapsulated in Cesare Nebbia's and Giovanni Guerra's fresco in the Salone Sistino of the Vatican Library. The focus of this work is the church of S. Maria Maggiore, from which a star-like network of streets expands outwards through all of Rome. The significance of the configuration of the streets is made clear in the distich above the fresco which associates it with the star of Bethlehem. In this capacity, the fresco echoes an argument made by Pope Gregory I against the Priscillian heresy that had recently been incorporated into Sixtus V's 1586 bull, Coeli et terrae: man was not made for the sake of the stars; rather, the stars were made for the sake of man. ${ }^{17}$ In other words, the stars could assist mankind in attaining full remission of sins. The text accompanying Nebbia and Guerra's fresco develops this notion further, noting that "when he opened the direct paths to the holiest churches, Sixtus himself opened the way to the stars." In this sense, the city's sacred places, were intended to be linked to the stars, and, by extension, could be used to aid in the remission of $\sin$ in a fashion analogous to that which Gregory I proposed for the stars. ${ }^{18}$

These vast urban projects begun by the Boncompagni pope during the first three years of his papacy were also reflected in the decoration to the Vatican Terza Loggia above the Damascus court. Begun by Pius IV, who had this third-storey Renaissance addition to the papal residence adorned with 13 modern maps of Europe, it was left to Gregory to complete the work of his predecessor with the addition of a dualhemisphere world map, along with maps of Asia, the Americas and Africa. At much the same time, Gregory commissioned Ottavio Mascherino to build a long, prestigious corridor on the west side of the Belvedere Courtyard. This he had decorated with 40 massive regional maps of Italy, giving the corridor the name by which it is generally known, Galleria delle Carte Geografiche, the Gallery of Maps. However, the iconography of the Galleria was more complicated than this, for the regional maps were linked to depictions of events in biblical and church history above them on the ceiling, thereby connecting the geography of the peninsula with the development of the Romana Ecclesia (Figs. 6.6 and 6.7).

The iconographic program of the Galleria as well as the one of the Terza Loggia were also combined with the one in the Sala Bologna to support Gregory XIII's plan

51 (1972): 383-402 and ibid., "La Roma di Pio IV, Parte II: il sistema dei centri direzionali e la rifondazione della città," Arte illustrata 54 (1973): 186-212; S. Benedetti, Giacomo del Duca e l'architettura del Cinquecento (Rome, 1973); as well as S. Benedetti and G. Zander, L'arte in Rome nel secolo XVI, I. L'architettura (Bologna, 1990).

${ }^{17}$ Gregory the Great, "Homily X" in Homiliarum in Evangelia Libri Duo (Migne PL 76.1112A): "Neque enim propter stellas homo, sed stellae propter hominem factae sunt." Cf. Tomassetti, Bullarium Romanum, VIII. 646: "Absit, inquit, a fidelium cordibus, ut aliquid esse fatum dicant, vitam quippe hominum solus hanc conditor, qui creavit, administrat, neque enim propter stellas homo, sed stellae fatum hominis esse dicitur, ipsis suis ministeriis subesse homo perhibetur."

18 "Dum rectas ad templa vias sanctissima pandit / ipse sibi Sixtus pandit ad astra viam." For Sixtus's network of roads and its connection to the Star of Bethlehem see Steven F. Ostrow, Art and Spirituality in Counter-Reformation Rome: The Sistine and Pauline Chapels in S. Maria Maggiore (Cambridge; New York: Cambridge University Press, 1996), 61-62; cf. René Schiffmann, Roma felix: Aspekte der städtebaulichen Gestaltung Roms unter Sixtus V. (Bern: Frankfurt a. M., 1985), 123. 


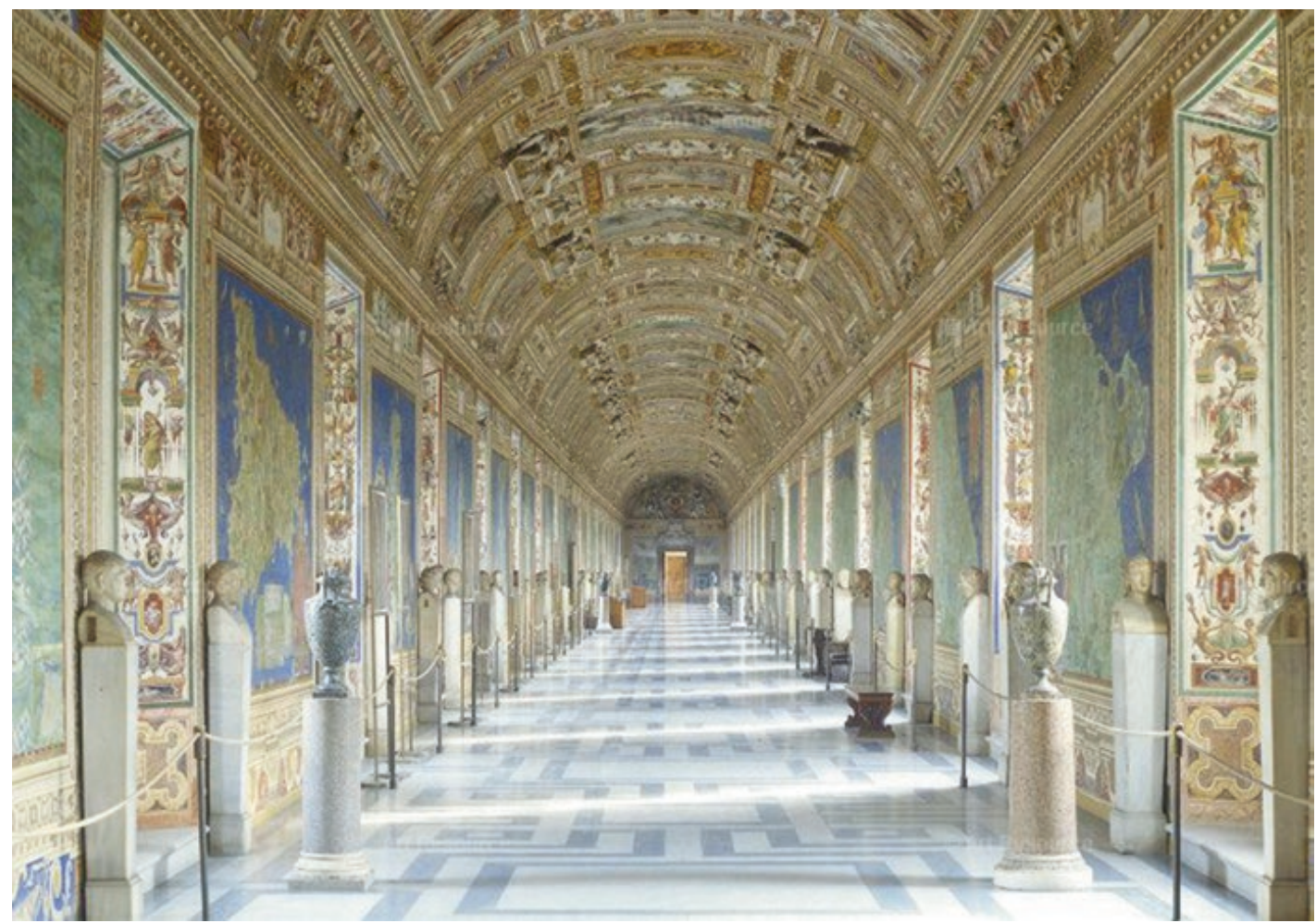

Fig. 6.6 View of the Galleria delle Carte Geografiche, Vatican

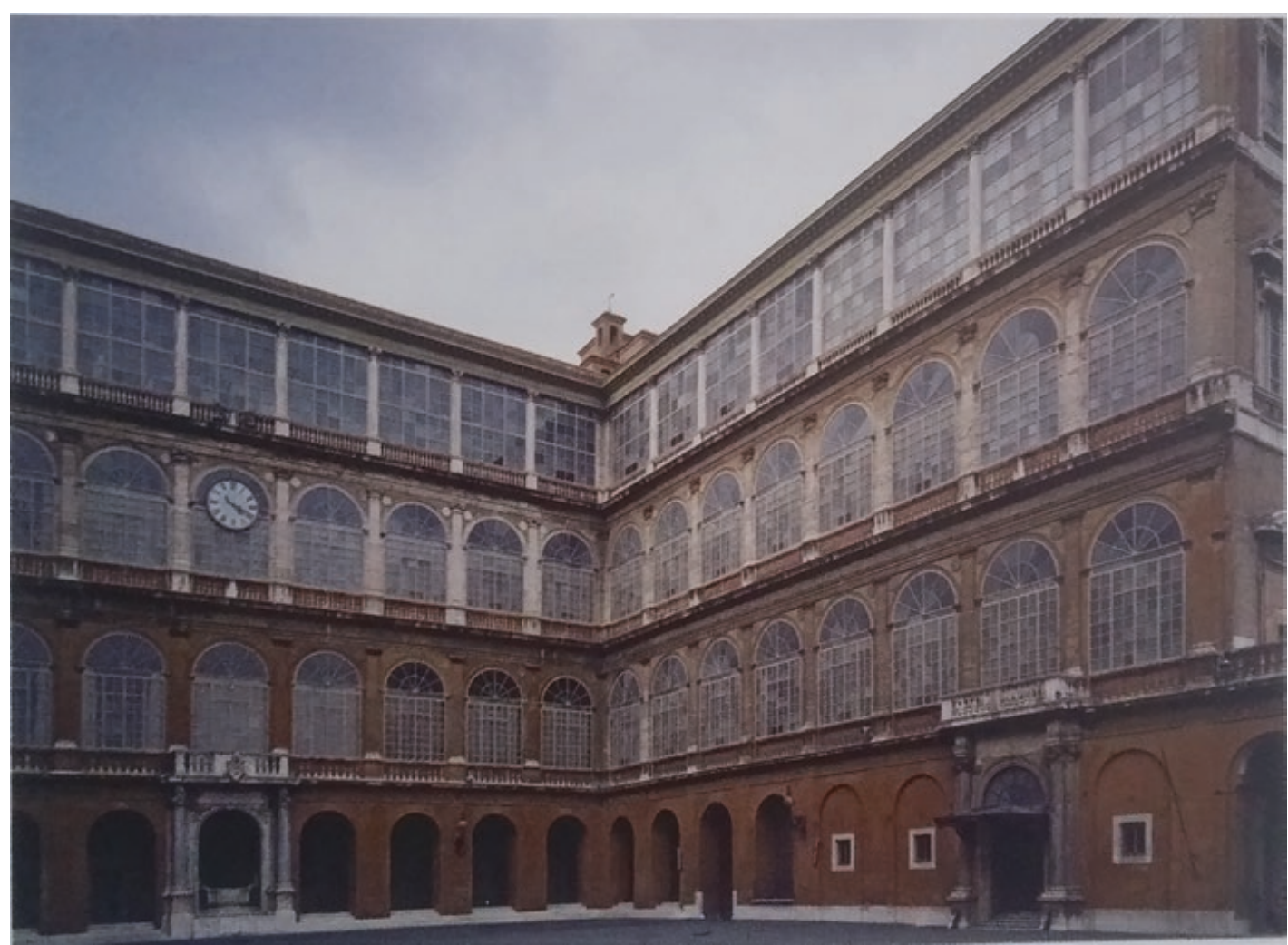

Fig. 6.7 View of Damasus Court, Vatican 
of church reform, the process that culminated in the publication of the Kalendarium Gregorianum and the Martyrologium Romanum in 1582 and 1583. The link between the reform of the calendar and the pope's Vatican decoration campaigns is closer than one might initially suspect. To be sure, the reform of the Julian calendar was made on the basis of recent astronomical investigations and calculations made by Luigi Giglio (Aloysius Lilius) regarding the cycles of epact which were summarized in the 1577 Compendium novae rationis restituendi Kalendarii. But it is clear from the 1580 report Ratio corrigendi fastos confirmata, et nomine omnium, qui ad Calendarii Correctionem delecti sunt which outlined some of the preconditions and approaches to calendar reform, and Gregory's 1582 bull Inter gravissimas which promulgated the change, that membership of the commission involved in the reform of the calendar overlapped with those charged with the decoration program. Despite the connection between these two projects, to date, scholars have not attempted to delineate the influence of the pope's decoration campaigns on the work of the calendar reform commission, or the former's influence on Cesare Baronio's 1586 edition of the Roman Martyrology. It remains unclear as to whether Baronio was also involved in designing the Vatican gallery's iconographic program. ${ }^{19}$ But rather than regard the Galleria, Gregory's Sala Bologna and the Terza Loggia with the reform of the calendar and the martyrology as part of a single project connecting the celestial and cosmographical realm to that of the terrestrial and geographical, scholarship so far has treated them as separate campaigns.

The Sala Bologna, Gregory XIII's private dining room in the Apostolic Palace built and decorated for the jubilee year, was an early example of this transition from the cosmographic to terrestrial plane-from cosmography to geography. As its name suggests, the room is a celebration of the pope's native city and features on its walls a large fresco map of the city. More significant for the current argument, though, is the vault decoration and its relationship both to the frescoes on the lateral walls and the pope's draconic emblem. The rectangular vault, as designed by the papal architect Ottavio Mascherino in a drawing now in the Biblioteca Comunale of Palermo, connects the iconography of the pope's native city by means of a loggia prospettica into which are inserted ten figures. ${ }^{20}$ These ten figures resemble, as

\footnotetext{
${ }^{19}$ There is debate as to whether this particular decoration was the work of a principle designer, as Margret Schütte has argued, or if the project was a collaboration, which was put forward by Iris Cheney and Marcia Milanesi. See Schütte, Die Galleria delle Carte Geografiche im Vatikan: Eine ikonologische Betrachtung des Gewölbeprogramms (Hildesheim, 1993), 12 \& 18. Cf. Millanesi, "Geography and cosmography in Italy from fifteenth to seventeenth century," Memorie della società astronomica Italiana 65 (1994): 443-68 and Cheney, "The Galleria delle Carte Geografiche at the Vatican and the Roman Church's View of the History of Christianity," Renaissance Papers (1989): 21-37.

${ }^{20}$ The figures were executed by the Bolognese artist Lorenzo Sabatini. Beginning at the northern end of the Sala, the figures themselves develop a progression ranging from the Old Testament figure of Seth to the medieval astrologer Alfonso X of Castile. However, the fictive loggia can be ascribed to the architect Mascherino through a preparatory drawing conserved in the Biblioteca Communale di Palermo. The Hessisches Landesmuseum in Darmstadt bears two drawings, which have for a long time been attributed to Federico Zuccari, but are now identified as Sabatini's preparatory drawings for the figures of Thoth and Atlas. For this see esp. L. Marinig, "Due disegni di
} 
Emily Urban has convincingly demonstrated, the fathers or inventors of astrology/ astronomy and western geography. But these figures were not chosen by the pope to adorn his room because they represented the variety of knowledge needed to carry out the reform of the calendar, as has been argued by scholars such as Francesca Fiorani and K. Lippincott. ${ }^{21}$ Rather, they are there because they illustrated the evolution of astrology/astronomy and geography from their mythological and biblical origins into the Middle Ages (Figs. 6.8 and 6.9).

This progression from biblical to historical time is also a key element in the vault decoration in the Sala, for it draws upon the Ptolemaic Planisphaerium - a fundamental source during the Italian Quattro- and Cinquecento-for details about constellations and for lines of longitude. The vault features a fresco map of heaven, for which Ptolemy's Geographia-and perhaps even Albrecht Dürer's 1515 xylography of the northern hemisphere-likely served as prototypes. It is quite clear that the ceiling fresco of the Sala was intended to serve an entirely different function to that commissioned by Cardinal Alessandro Farnese at Caprarola for his Sala della Cosmografia to which it is often compared..$^{22}$ The Farnese sky map which is part of the Caprarola Sala is an integral component of an elaborate visual rhetoric of decoration intended to articulate the cardinal's ambition to be elected pope, begun after his loss to Boncompagni in the papal elections of 1572. By contrast, it seems clear from the lines of longitude defining the Arctic and Antarctic as well as the zodiacal symbols along the lines of eclipse that the Vatican fresco seems more concerned with presenting an accurate depiction of the heavens than inviting their allegorical reading. This point is underscored by the fact that while the cardinal's Sala was intended to be a public space; that of the pope was private.

Thus, the decoration of the Sala Bologna suggests on the one hand a celebration of the cartographic arts and their importance for reform during Gregory's pontificate. But on the other, the cartographic precision with which the images were executed suggests an affirmation of papal control over the celestial world. Indeed, taken together with the Terza Loggia and the Galleria delle Carte Geografiche, the scale of the decorative program promoted by the pope was intended to transform the Vatican Palace into the only place where it was possible to admire the most complete

Lorenzo Sabatini per gli affreschi della sala Bologna in Vaticano," in Scritti di storia dell'arte in onore di Jürgen Winkelmann, ed. S. Béguin, M. Di Giampaolo, and P. Narcisi, 185-195 (Naples, 1999), 185. For the drawing in Palermo, see esp. S. Prosperi Valenti Rodinò, I disegni del Codice Resta di Palermo (Milan, 2007), 92.

${ }^{21}$ See Fiorani, Marvel of Maps, 149 and K. Lippincott, “Two Astrological Ceilings Reconsidered: The Sala di Galatea in the Villa Farnesina and the Sala del Mappamondo at Caprarola," Journal of the Warburg and Courtauld Institutes 53 (1990): 185-207, at 206. More convincing is Emily Urban's "La volta celeste dell Sala Bologna e la tradizione della cosmografia rinascimentale," in La Sala Bologna nei Palazzi Vaticani: Architettura, cartografia e potere nell'età di Gregorio XIII, ed. Francesco Ceccarelli and Nadja Aksamija, 57-64 (Venice, 2011), 58.

${ }^{22}$ Regarding the Caprarola ceiling, see L. Partridge, "The Room of Maps at Caprarola, 1573-75," The Art Bulletin 77 (1995): 413-444 and M. Quinlan-McGarth, "Caprarola's Sala della Cosmografia," Renaissance Quarterly 50 (1997): 1045-1100. 


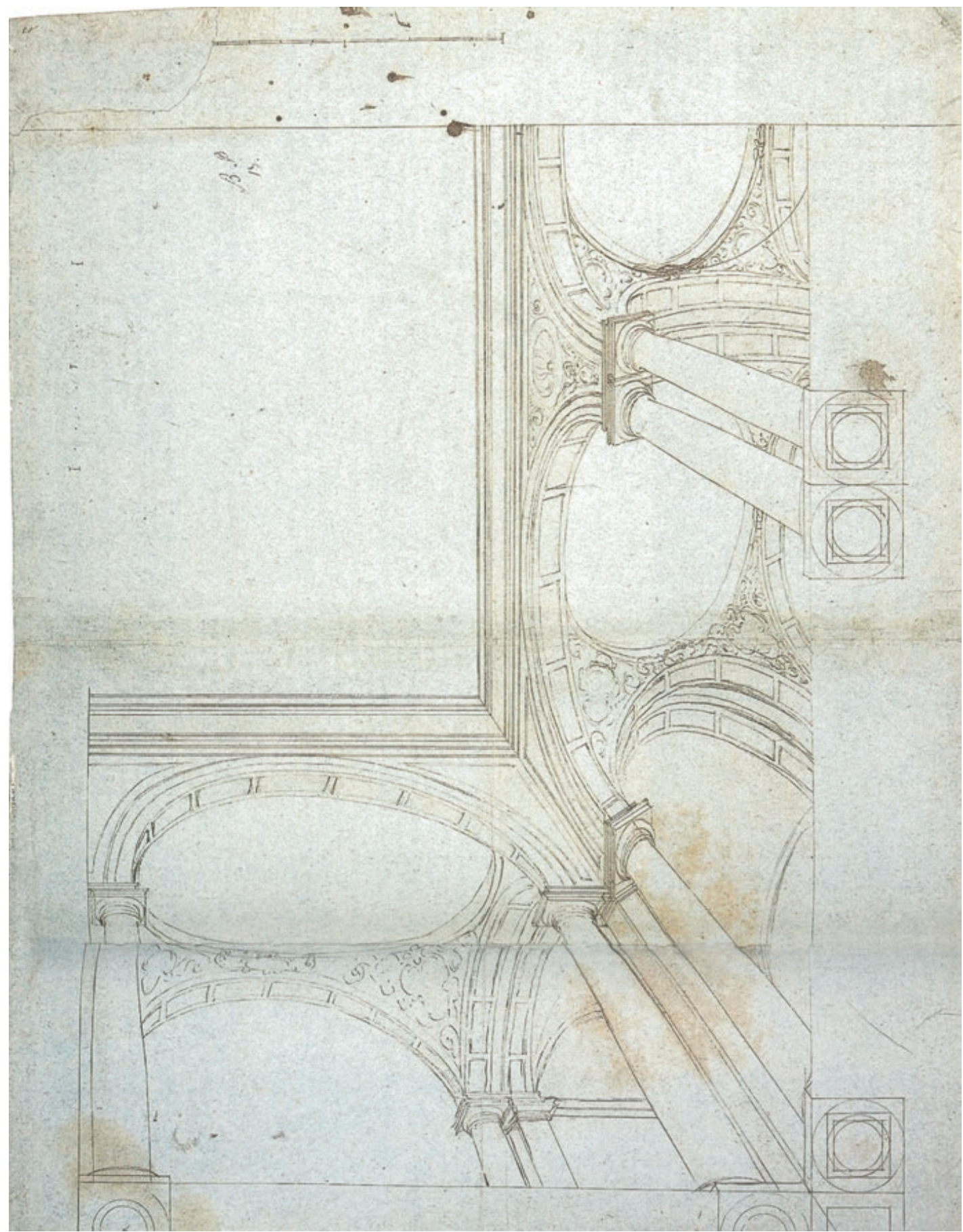

Fig. 6.8 Ottaviano Mascherino, Preparatory drawing for the vault of the Sala Bologna, drawing by pen, 1575. From Francesco Ceccarelli and Nadja Aksamija, La Sala Bologna nei Palazzi Vaticani: Architettura, cartografia e potere nell'età di Gregorio XIII (Venice, 2011), 61, fig. 6. (Codice Resta, Biblioteca Comunale di Palermo, Palermo) 


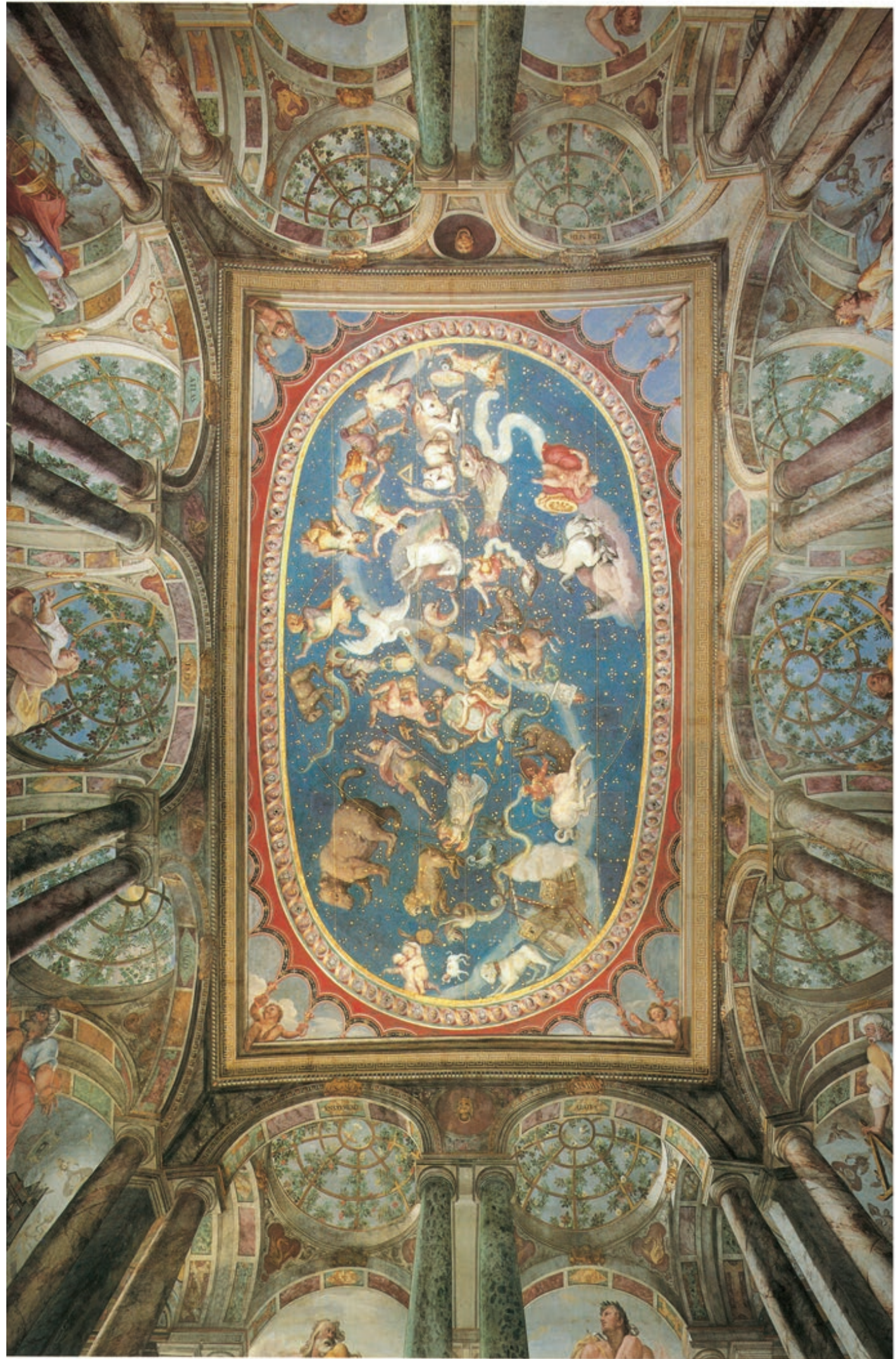

Fig. 6.9 Giovanni de' Vecchi, Vault of Sala del Mappamondo, Palazzo Farnese, Caprarola (Scala Archives) 


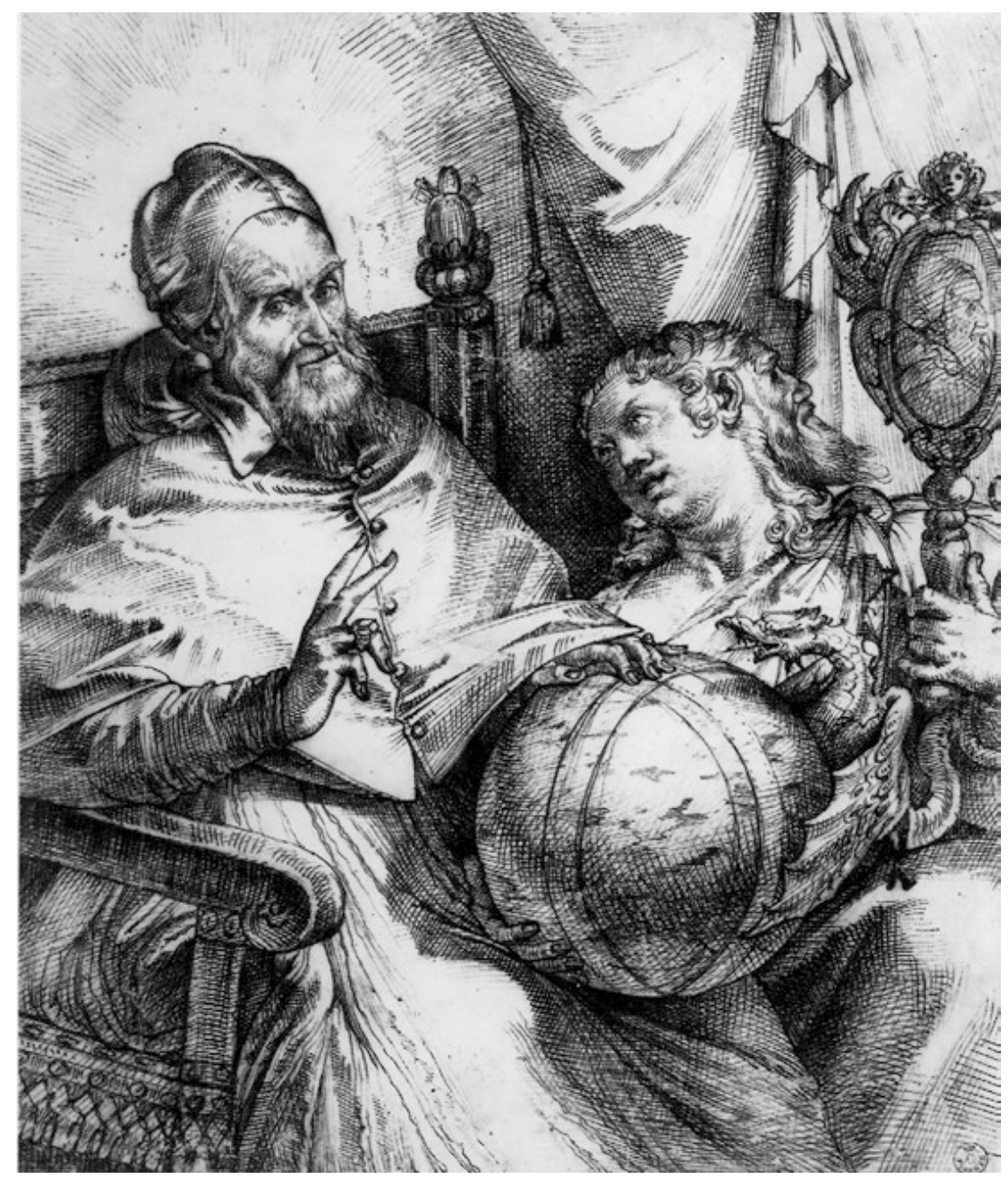

Fig. 6.10 Bartolomeo Passerotti, Gregory XIII, drawing in ink and pen, 1572. From Francesco Ceccarelli and Nadja Aksamija, La Sala Bologna nei Palazzi Vaticani: Architettura, cartografia e potere nell'età di Gregorio XIII (Venice, 2011), 15, fig. 4 (Gabinetto Disegni e Stampe, Galleria degli Uffizi, Firenze)

representation of the terrestrial and celestial worlds - the two worlds over which the pope claimed control (Figs. 6.10 and 6.11).

This ambitious decorative program at the Apostolic Palace began during the early years of Pope Gregory's pontificate when he commissioned a group of Bolognese artists to have his portrait painted. However, as Lorenzo Sabatini, one of the painters, remarked, "the pope wanted to be portrayed only once by me and by [Bartolomeo] Passerotti, and not by anyone else." ${ }^{23}$ Indeed, a splendid likeness by Passarotti is preserved in the Uffizi, which shows Gregory seated in his papal chair wearing the camauro on his head and the mozzetta over his shoulders. His right hand is elevated as if giving benediction, while his left is laid over a globe that has

\footnotetext{
${ }^{23}$ Letter from Lorenzo Sabatini to Prospero Fontana dated 7 March 1575, as quoted in A. Ghirardi, Bartolomeo Passarotti pittore (1529-1592) (Bologna, 1989), 127.
} 


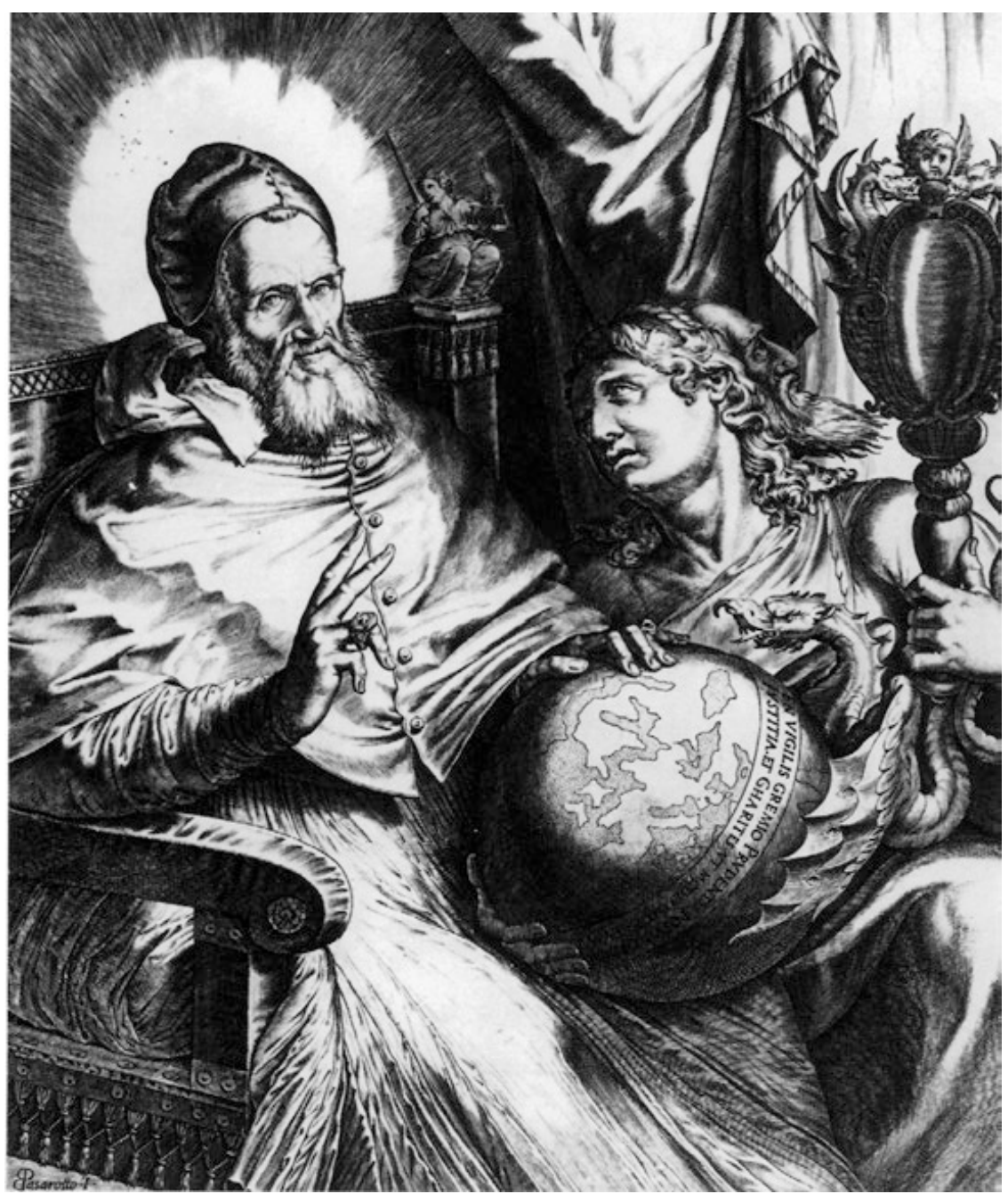

Fig. 6.11 Domenico Tibaldi, Pope Gregory XIII, engraving, 1572. From Francesco Ceccarelli and Nadja Aksamija, La Sala Bologna nei Palazzi Vaticani: Architettura, cartografia e potere nell'età di Gregorio XIII (Venice, 2011), 15, fig. 5 (Gabinetto Disegni e Stampe, Galleria degli Uffizi, Firenze)

been brought to him by an allegory of Prudence, recognizable by her double faces and a serpent in the mirror nearby. Significantly, though, Passarotti transformed the serpent into Gregory's heraldic dragon. This portrait was so widely diffused among Bolognese artists that Domenico Tibaldi, an artist who also provided help for the cartographic depictions in the Sala Bologna, made a splendid etching of Passerotti's work. Besides adding the figures of Justice and Charity atop the Papal sedia, Tibaldi complemented the globe with an inscription around the equator that reads as follows: "EN VIGILIS GREMIO PRUDENTIA POSUIT ORBEM / IUSTITIA ET CHARITES UT MODERENTUR EUM" (Behold, Prudence placed the world in the lap of the guard, so that Justice and Charity might govern it). The additions made clear that the pope intended not just to reform the Julian calendar, but the Roman Martyrologium as well. The prudent governance of the Catholic world through works of charity and justice that extended over the whole terrestrial globe 
lay in the pope's judicial supremacy, power which he automatically received through the apostolic tradition of his office.

\subsection{The Christianus Orbis Beneath Rome and Liturgical Reform as a Form of Collaboration}

Although the Vatican Galleria delle Carte Geografiche was not mentioned in the official books of ceremony, an avviso from July 1578 reports that the pope liked to take walks along the slopes of the Belvedere courtyard, and that audiences were occasionally held there. During the Holy Year, Gregory started to use the courtyard for religious ceremonies, too, often blessing pilgrims from one of the windows facing the main entrance to the Belvedere. ${ }^{24}$ The original decoration plan for the Vatican Galleria was to include an anamorphosis that would have been located at the south end of the Gallery opposite the entrance, so that the whole had the appearance of the Eucharist in a mirror reflected through a lens hidden above. This distorted projection stood in close relationship with the scenes of biblical sacrifices and can be considered to be the basis for the decoration, since they form a pictorial unity with the anamorphosis of the Eucharist. As the French cleric Jean Teard recorded in his travel memoirs when he visited Rome in 1593, the anamorphosis must have been placed high enough in order to be recomposed by a mirror. ${ }^{25}$ This specific mode of revealing the Host through the artifice of perspective also underscored the Eucharistic meaning not only of the sacrifice series but of all the episodes depicted in the vault of the gallery. The Dominican Ignazio Danti is the likely author of the gallery's anamorphosis, for he described its geometrical construction in his commentary on Giacomo Vignola's Le due regole della prospettiva practica (Two Rules on Perspective) in 1583. Indeed, he himself created such distorted projections, including one that was also a portrait of Gregory himself. ${ }^{26}$ The decorative program should thus be seen as developing from the Eucharistic foundations that the post-Tridentine papacy rigorously emphasized during Gregory's pontificate, and not from historiographical treatments of Emperor Constantine the Great's life, as scholarship so far has argued. ${ }^{27}$ The aforementioned transition from the heavenly to the terrestrial realm was also sophisticatedly incorporated in the decoration campaigns carried out under Gregory to promote a similar relationship between the task of completing the

\footnotetext{
${ }^{24}$ Avvisi di Roma, 22 July 1578 (BAV, Urb. Lat. 1046, fol. 288v).

${ }^{25}$ Jean Tarde, A la rencontre de Galilée: Deux voyages en Italie, eds. Francois Moureau and Marcel Tetel (Geneva, 1984), 40: "nous avons vu ... la galérie grégorienne, au bout de laquelle est. un miroir qui réprésente un calice avec l'hostie, prenant telle image d'un tableau qui est. au-dessous, sans que telle peinture y soit, mais c'est. par un artifice de perspective."

${ }^{26}$ See Le due regole della prospettiva pratica di M. Iacomo Barozzi da Vignola con i comentarij del R. P. M. Egnatio Danti dell' ordine de Predicatori, Matematico dello Studio di Bologna (Rome, 1583), 94-95.

${ }^{27}$ See, for instance, Foriani, Marvel of Maps, $209 \mathrm{f}$.
} 
reform of the Roman rite and the production of historiographical works that depicted the development of the Roman Church and the papacy. As a result, this unique understanding of the role of the Roman rite in the liturgy was also influenced by a sophisticated conception of the manifold properties of image production.

This same amplified significance of liturgical practices was also stressed in Gregory's apostolic constitution Emendato iam Kalendario, promulgated on 14 January 1584. This stated that a new edition of the martyrology should be compiled on the basis of contemporary astronomical knowledge which should explain its liturgical significance correctly. ${ }^{28}$ That the reform of the Martyrologium should be seen as a project being pursued in conjunction with the reform of the calendar is clear from a letter written by Vincenzo Lauro to the Secretary of State, Cardinal de' Como, dated 4 November 1581. This stated that "it would be necessary to publish the new martyrology at the same time as the new calendar." 29

The person in charge of both the commission for the reform of the Kalendarium and for the Martyrologium was Cardinal Guglielmo Sirleto. Although the members of the commission for the reform of the Roman martyrology are known, the degree to which Cesare Baronio was engaged in the liturgical reform still remains unclear. ${ }^{30}$ Nevertheless, his 1586 Tractatio in Martyrologium Romanum makes it possible to delineate some of the major factors underlying the commission's project. It is often argued that Sirleto handed over the task of publishing the new Martyrologium to Baronio because the work was historiographically complicated. To be sure, by 1579 Baronio had already completed the first three books of his Annales Ecclesiastici and

\footnotetext{
${ }^{28}$ Gregory XIII's apostolic constitution was included in the newly edited Martyrologium Romanum by the Oratorian Cesare Baronio. See Martyrologium Romanum: Ad novam Kalendarij rationem, \& Ecclesiasticae historiae veritatem restitutum (1584), ed. Manlio Sodi and Roberto Fusco, Monumenta Liturgica Concilii Tridentini II (Rome, 2005), 3, henceforth quoted as Martyr. Rom. Already the Roman Breviary from 1568 incorporated a provisional calendar reform, which sustains the dependency of scientific calculations from liturgical reforms and vice versa. The Spanish Franciscan Juan Salon published in 1576 a book entitled De Romani Calendarii Nova Emendatione, ac Paschalis Solemnitatis Reductione, in which the author stated the necessity of determining a more precise date for liturgical feast regarding Holy Week than the old calendar.

${ }^{29} \mathrm{BAV}$, Vat. lat. 6417, 51-52. His proposed formulation reads, Calendarium, ad quod etiam accommodata est. ratio martyrologii. The final text was then: ... Calendarium immensa Dei erga Ecclesiam suam benignitate iam correctum atque absolutum hoc nostro decreto probamus, et Romae una cum Martyrologio imprimi, impressumque divulgari iussimus. As quoted in A. Ziggelaar, "The Papal Bull of 1582 promulgating a reform of the Calendar," in Gregorian Reform of the Calendar: Proceedings of the Vatican Conference to commemorate its 400th anniversary, 1582-1982, ed. G. V. Coyne, M. A. Hoskin and O. Pedersen, 201-239 (Vatican City, 1983), 224.

${ }^{30}$ As early as a letter dated 6 December 1580 , Baronio described himself to his father as having been appointed a member of the commission by Sirleto. See BV, Q 46, fol. 49: "Sua Santità si serve di me nella riformatione del Martyrologio, per quale si fa una congregazione d'huomini eccllenti, et il reverendissimo Sirleto mi ha eletto per uno di quelli." The most detailed work reconstructing Baronio's contribution to the Martyrologium remains Giuseppe A. Guazzelli, "Cesare Baronio e il Martyrologium Romanum: problemi interpretativi e linee evolutive di un rapporto diacronico," in Nun alia tempora, alii mores: Storici e stoia in età posttridentina, ed. Massimo Firpo, 47-89 (Florence, 2005).
} 
so had already made a significant contribution to the iconographic design of the Vatican Galleria delle Carte Geografiche. ${ }^{31}$ But such an explanation is too simplistic, for it does not consider the fact that Baronio's first volume of the Annales was published nearly 10 years after the decorations in the Vatican Galleria. This fundamental chronological detail has been glossed over in much of the scholarship considering Baronio's probable contributions to pivotal pictorial programs in Rome during the second half of the Cinquecento. ${ }^{32}$ The following argument thus develops a rather different picture. Namely, it attempts to trace Baronio's perception of such iconographic designs and how those influenced him in his editing of the new Martyrologium.

In the fourth chapter of his Tractatio, Baronio makes a distinction between what he sees to be the two principal forms of the cult of martyrs in the early Christian period. One consisted of a liturgical celebration of the Eucharist on the martyr's birthday. The other focused on the commemoration of the martyrdom in specific Roman churches. ${ }^{33}$ Baronio was also especially concerned with the visible expression of the cult of martyrs which could be observed during his own day. This was true in the case of the translation of Gregory of Nazianzus' relics from S. Maria in Campo Marzio to the newly erected Cappella Gregoriana in St. Peter's. By this point, Baronio had written a biographical account on the fourth-century archbishop of Constantinople, and this must have served as the basis for the translation ceremony. ${ }^{34}$

\footnotetext{
${ }^{31}$ See esp. Pauline Moffitt Watts, "The Donation of Constantine, Cartography, and Papal Plenitudo Potestatis in the Sixteenth Century: A Paper for Salvatore Camporeale," Modern Language Notes (MLN) 119 (2004): 88-107, at 91. In fact, only the first two volumes could be published nearly 10 years later, while the third came out in 1592/93. See further on this F. Malesevic, Kardinal Caesar Baronius: Kirchenhistorik und Kunstpatronage im post-tridentinischen Zeitalter der Päpste (Saarbrücken, 2015), $60 \mathrm{f}$.

${ }^{32}$ For more detail, see Romeo De Maio ed., Baronio e l'arte, Atti del convegno internazionale di studi, Sora, 10-13 October 1984 (Sora, 1985) and more recently in Patrizia Tosini ed., Arte e committenza nel Lazio nell'età di Cesare Baronio, Atti del convegno internazionale di Studi, Frosinone, Sora, 16-18 May 2007 (Rome, 2009).

${ }^{33}$ Mart. Rom. (1586), iv: "Sicut olim Romae notarijs de conscribendis sanctorum Martyrum actis, ita $\&$ in alijs ecclesijs, etiam transmarinis alicui ex clero negorium fuisse videtur impositum, qui quisq(ue); martyris natalem diem (six enim appellare consueverunt die, in eiusdem sancti Martyris memoriam Deo offerretur sacrificium [...] Ori natalijs annua die facimus facere enim idem esse penes antiquos, quod fabricare, opportuniori loco inferius, cum agimus de Pontificis voce, monstramus [...] Denique \& dies eorum, quibus excedunt adnotate; ut commemorationes eorum inter memorias Martyrum celebrare possimus [...] quam fratribus in omni osequio operationis imperrit, qui nec illic circa curam corporum deest [...] ad significet mihi dies quibus in carcere beati fratres nostri ad immortalitatem gloriosae mortis exitu transeunt, \& celebrantur à nobis hic oblationes \& sacrificia ob commemorationes eorum [...]"

${ }^{34}$ Originally, Baronio's work was commissioned by Pope Gregory XIII himself to be included in the ongoing works on the Acta Sanctorum, for Baronio also commenced a biography of St. Ambrose that he dedicated to Felice Peretti, the future Pope Sixtus V. For this, see the earliest edited collection of Baronio's letters in Raymundus Albericius, Venerabilis Caesaris Baronii S. $R$. E. Cardinalis Bibliothecarii Epistolae et Opuscula, 3 vols (Rome, 1759-1770), vol. 1, 165-168. The diaries of the ceremonial masters Francesco Mucanzio and Paolo Alaleona regarding the orga-
} 
Another important element that points to Baronio's early work on the Martyrologium is the treatment of the city of Rome as the geographical epicenter of worship, a point stressed by the city's association with the two principal apostles, Saints Peter and Paul. Pius V's Breviarum Romanum from 1568 already confirmed the character of these recurring celebrations by emphasizing Rome as the festive focus for their celebration. ${ }^{35}$ Through the Roman basilicas dedicated to them, for Baronio, Peter and Paul represented visible manifestations of the Romana Ecclesia, which functioned as true imagines. ${ }^{36}$ In this way, the two apostles were thus taken as prefiguratory exempla for each subsequent saint's life. In turn, marvels and events taken from the history of the Roman Church could also be deemed imagines, since they were understood as the result of the particular actions of each saint, and thus could be claimed authentic. For instance, the authenticity of Saint Francis'stigmata was accepted by Pope Gregory and consequently included in the Martyrologium. In the later 1586 edition of the Martyrology, Baronio noted that "these sacred stigmata could be seen and adorned through the celebration of Saint Francis' birthday." Although Baronio's letter dates from the period after Felice Peretti's elevation to the papacy as Gregory XIII's successor, the inclusion of Francis' stigmata must have been discussed before 1585 and therefore must have been an issue for Baronio when he began his early work on the Martyrologium. ${ }^{37}$

The Martyrologium Romanum goes beyond this, though, for it not only presents a collection of Roman martyrs but also includes those from the various provinces of the Christianus Orbis. In this sense, the text not only affirmed a universal celebratory status of Christian martyrs, but assigned a spatial dimension to the wider practice of devotion. ${ }^{38}$ This furthermore underscored the curia's general claim that the

nization of the apparatus must also be read in close relation with Baronio's biography. See BAV, Vat. lat. 12,286, fol. 373v. \& 314-373; and Giovanni Rastelli, Descrittione della Pompa et del Apparato fatoo in Roma per la traslatione del Corpo di S. Gregorio Nazianzeno dal Monistero di S. Maria in Campo Marzio nella Chiesa di S. Pietro nella Cappella Gregoriana (Perugia, 1580), as well as Fortuno Lelio, Pompa et Apparato fatto in Roma nel giorno della Traslatione del Como di San Gregorio di Nazianzeno da Santa Maria in Campo Marzio nella Cappella Gregoriana (Venice, 1585).

${ }^{35}$ See Breviarum Romanum: Editio princeps (1568), ed. Manlio Soldi and Achille Maria Triacca (Vatican City, 2012), 797-806 (In Festo Apostolorum Petri \& Pauli. Ad Vesperas antiphona). This dependency on earlier reforms of liturgical books must also have been instrumental for Baronio's composition of his Annales Ecclesiastici.

${ }^{36}$ Mart. Rom. (1586), 520. cf. ibid., 289, where he argues: "Romae natalis sanctorum apostolorum Petri et Pauli qui eodem anno, eodemque die passi sunt sub Nerone imperatore: quorum prior in eadem Urbe capite ad terram verso cruci afficus, et in Vaticano iuxta viam Triumphalem sepultus, otius Orbis veneratione celebratur; alter vero gladio animadversus et via Ostiensi sepultus, pari habetur honore."

${ }^{37}$ See the letter in Albericius, Epistolae et Opuscula, vol. 1, 169-170, where the annotation to Saint Francis' birthday on 17 September is given. However, the note was included on behalf of Sixtus in the 1586 edition, for he himself was a Franciscan.

${ }^{38}$ This point was made by Guazzelli, "L'immagine del Christianus Orbis," 181. Such ascriptions did, however, undergo a serious verification, as the case of the celebratory cult of Saint Eutropia demonstrates. While the 1583 edition supposed that its cultural epicentre was in Anglia, the edition from 1584 adopted a variant which saw events taking place in Gallia. See for this Mart. Rom. (1584), 285 as well as Baronio's annotation in ibid., 417-418. 
Roman practice of celebrating each martyrs' birthday during the liturgical year had indeed a basis in physical reality grounded in the long history of the city of Rome itself.

But in his approach to the Martyrologium Romanum, it seems likely that Baronio might also have cooperated significantly with the commission that brought out the Gregorian calendar, for in accordance with the pope's constitution, Baronio connected the liturgical celebrations with the office of the papacy thus making the Martyrologium a specific dedicatory form to the papacy's accomplishments throughout the evolution of the Roman Church from early Christianity by placing it within an apostolic tradition that continued the deeds of Saints Peter and Paul. Situating the papacy in the context of the early Christian martyrs was intended to emphasize the role the office of episcopacy played in the curia's attempts not only to reform the liturgical books, but also to separate the interpretation of astronomical phenomena from astrological superstitions as the Tridentine rules also decreed.

Already an important theme in the decorative campaign of Gregory's Sala, Bologna also received a prominent place in Cesare Baronio's revised Martyrologium Romanum, by linking the city's first bishop-Saint Zama-to Rome through his ordination by Pope (and later saint) Dionysius. ${ }^{39}$ In the 1586 edition of the Martyrologium, Baronio noted that for this he had drawn from the Modenese historian Carolo Sigonio's De episcopis Bononiensibus, left unfinished at Sigonio's death in $1584 .{ }^{40}$ This, in turn, was likely inspired by Gabriele Paleotti's 1583 visit to Rome to receive the archbishop's pallium when the city was elevated to the status of metropolitan. Paleotti is important because a year before his visit to Rome, he published his famous Discorso intorno alle immagini sacre e profane. Among other things, this stressed the importance of the role of bishops in overseeing the production of sacred images so that they conformed to Christian doctrine and inspired divine contemplation.

In a chapter entitled Delle pitture profane che rappresentano varie cose come guerre, paesi, edifici, animali, arbori, piante e simili, Paleotti argued that some profane images could function as sacred ones if they contributed to metaphysical contemplation. He affirmed that this could only happen if such images were based on the direct observation of natural phenomena and that the pleasure (diletto) they caused was solely dependent upon the images' didactic value. Furthermore, Paleotti

\footnotetext{
${ }^{39}$ Mart. Rom. (1584), 58 (24 January): "Bononiae sancti Zamae primi eiusdem civitatis episcopi, qui a sancto Dionysio Romano Pontifice ordinatus, illic Christianam fidem mirifice propagavit."

${ }^{40}$ Mart. Rom. (1586), 49, n. g: "De eodem tabulae Ecclesiae bononiensis. Legi commentarium nondum typis excusum de Ecclesia bononiensis, quo series Episcoporum eius atque ipsorum res gestae narrantur, quem Sigonius vir quidem disertus conscripsit hortatu amplissimi Cardinalis Paleoti archiepiscopi bononienis." Sigonio's manuscript was already accessible as a first draft to Gabriele Paleotti, Bologna's archbishop, in 1572. For this see William McCuaig, Carlo Sigonio: The Changing World of the Late Renaissance (Princeton, 1989), 90. Sigonio's importance for the cultural renovation of Bologna was ongoing during Paleotti's episcopacy. See in general Paolo Prodi, "Vecchi appunti e nuove riflessioni su Carlo Sigonio," in Nun alia tempora, alii mores: storici e storia in età posttridentina, ed. Massimo Firpo, 291-310 (Florence, 2005).
} 
considered such images that stemmed from the observation of natural phenomena to pertain to the order of images that "may not convey virtue and the service of human life." ${ }^{41}$ He even included Thomas Aquinas's condemnation of astrology from the Summa Theologiae arguing that "painters are reminded to have nothing to do with designs or figures that may show natal constellations, or celestial signs, or the planets, or other such things that might signify some necessity governing human actions, or that might convey that message to the simple and ignorant." ${ }^{42}$ In this sense, Sabatini's sky map in the Sala Bologna ought not to be construed as a chart of the heavens devoid of astrological references, but more simply as an illustration of the sky. It should be regarded as more powerful, more useful, for, as Paleotti saw matters, in meditating on the terrestrial world and its representation in images, viewers can be drawn towards contemplation of the divine.

Paleotti's Discorso also included his own observations about the frescoes of martyrdom in the church of S. Stefano Rotondo which he saw during his stay in Rome between 1582 and 1583. For him, these images worked in much the same way, drawing the mind closer to God:

... every day we observe the atrocious tortures of the saints depicted and minutely expressed, with the wheels and the headsmen and the iron-bound torture grates, and the mounds of fire, and the gratings, and the wooden torture horses, and the crosses and countless other cruel torments minutely expressed. The Catholic Church has approved their being represented before the eyes of Christian folk, as heroic insignia of the patience and great-mindedness of the holy martyrs and trophies of their unconquered faith and glory; our zealous mother wishes her sons to take heart from their example, and learn to spurn life-should occasion demand-for the divine service, and to adopt an attitude of constancy in all the accidents of this world. She also intends horrendous images to remind us of how incomparably greater the pains and afflictions of the martyrs were than the ones we are feeling in the infirmities and miseries of this life so that we learn to bear and disdain with virility things that may perturb one's faith in God and desire for this glory swelling within us. ${ }^{43}$

Baronio makes a similar argument in the ninth chapter of his Tractatio to the 1586 edition of the Martyrologium Romanum. Here, he asserts, the visible can be rendered in such a way that it can function as a mediator between the physical and metaphysical. In this specific context, it brings the viewer to a heavenly realm of contemplation, thereby reinforcing the celebrative character of the veneration of the

\footnotetext{
${ }^{41}$ Gabriele Paleotti, Discourse on Sacred and Profane Images, trans. William McCuaig (Los Angeles, 2012), 215-218.

${ }^{42}$ Paleotti, Discourse, 217. That this thought was transmitted to Paleotti by Ignazio Danti and Ulisse Aldrovandi can be confirmed by the fact that these scholars were two of the first readers of Paleotti's treatise. Indeed, Danti dedicated his 1578 Anemographia to Paleotti, recalling the dedicatee's arguments about the intermediary role of the mixed sciences between physics and metaphysics. Citing Augustine, Jerome, and Gregory of Nazianzus, Danti argued that these mixed sciences "elevate the intellect, and sharpen [one's] wits to the contemplation of the divine." See Ignazio Danti, Le scienze matematiche ridotte in tavole (Bologna, 1577) as well as Fiorani, Marvel of Maps, 156-157.

${ }^{43}$ Paleotti, Discourse, 257.
} 
martyrs of late antiquity, linking a liturgical practice to the sacred space under Rome's topographical surface. ${ }^{44}$

Pope Gregory XIII's desire to reform the liturgical book of the Martyrologium was, therefore, not inspired primarily by a desire for historiographical correctness, but by the desire to reserve the claim to universality which the Roman Church-and consequently the papacy itself_-ambitiously sought for itself after the Council of Trent. The pope's emblematic dragon was thus only able to function appropriately if the issue of what constituted a proper imago was correctly defined. In this sense, astronomical phenomena that were initially connected with the apocalyptic message implied by Gregory's emblem could be reframed in the manner exemplified by Ulisse Aldrovandi or Gabriele Paleotti. In fact, both naturalists and theologians also made a fundamental distinction between imago and simulacrum. This crucial difference was that the interpretation of physical appearances such as astronomical phenomena and the catacombs endorsed by the Romana Ecclesia pertained to the category of sacred images and so was related to the notion of imago. By contrast, simulacra were those images that belonged to a "false cult of God" and thus negatively connoted. ${ }^{45}$ That the Oratorian and later Cardinal Cesare Baronio was also more interested in the reaffirmation of a proper imago than the historiographical problems the Martyrologium Romanum entailed can be concluded from his many references to collaborative circles in the Roman Curia as well as to the principle iconographic programs that supported the goals of reforming the liturgy according to the Tridentine decrees. The result Baronio aimed at achieving with the newly edited Martyrologium was to bring to the surface the cult of martyrdom that-until the discoveries on the Via Salaria Nuova in 1578-lay beneath the apostolic urbs of Saints Peter and Paul. Its proper admiration as well as veneration of reliquary visibility was thus being stimulated by the Oratorian's work on this liturgical book.

\footnotetext{
${ }^{44}$ Mart. Rom. (1586), *X: "Nec est. praeterea, quod quis miretur, si in eodem ipso, de quo agimus Romano Martyrologio, clarissimos illos martyres videat praetermissos, quos nostro seculo, ob tuendam, propagandamque catholicam fidem poenas atrocissimas, si qui alii olim martyres, in Anglia potissimum atque in Galiis ab haereticis passos, et in coelum (ut par est. credere) recensitos inter alios martyres aequali scimus triumphi gloria cooptatos; nec illos inveniat recensitos, qui velut tonitrui filii, in similitudinem fulguris coruscantis novo Orbi evangelico lumine illuxerunt, ac fidei casa martyrium subiere. Non enim (ut apparet) fuit in praesens Romanae Ecclesia institutum, novum conscribere Martyrologium, sed vetus (ut diximus) ex veteribus exemplaribus restituere."

${ }^{45}$ See esp. the difference made by Paleotti, Discourse, 88-90 and clearly echoed in Ulisse Aldrovandi's statement made upon writing on his own naturalistic collection: "queste figure paiono propriamente il simolachro istesso di natura, che aggabba gl'occhi de riguardanti." As referred in n. 23 above., Baronio himself incorporated this crucial difference between imago, simulacrum and idolum in his Annales Ecclesiastici, which first two volumes were published in 1588 and 1589. See Caesar Baronius, Apparatus in Annales Ecclesiasticos Caesaris Baronii, cum critice pagii \& notis (Lucca, 1740), 395-399.
} 


\subsection{Conclusion}

While the Martyrologium Romanum constructed a history of a subterranean civitas of early Christian Rome, the contemporary discursive frame conditioning the interpretation of celestial phenomena stressed the city of Rome as a reflection of the skies above the Eternal City. However, as the argument above has attempted to show, these circumstances were not disconnected from each other. The relationship between these two poles highlights a genuine concern for the city of Rome during a tumultuous period after the Tridentine council when the curia had to provide an acceptable explanation for why the newly elected pope, Gregory XIII, chose to keep as his emblem the apocalyptic dragon of the Boncompagni family. This was primarily established through the decoration of the pope's private Sala Bologna and the Galleria delle Carte Geografiche, the corridor that connected the curia's private apartments with the official ceremonial interiors of the Vatican Apostolic Palace.

The strong correlations between the pope and his native city of Bologna that this emblem suggested by its pictorial diffusion through other treatises, such as the engravings in Principio Fabrizi's Delle Allusioni, also had important consequences for how the pictorial program of the pope's private interior and the connecting corridor related to each other in respect to the renewed understanding of the city of Rome. The city is not only to be considered the center of the Christian orbs because of its importance for the historical reconstruction of martyrdoms that occurred there, but also because the Boncompagni's heraldic dragon has been successfully reinterpreted as an evidentiary symbol protecting pilgrims visiting the Eternal City during Jubilee Year of 1575 for the remission of their sins. Cesare Baronio's Martyrologium Romanum, therefore, must have been influenced extensively by this renewed appreciation that Rome especially received after the rediscovery of the tombs of early Christian martyrs in 1578. Furthermore, Baronio's work could make an important contribution in that it constituted a fundamental building block of the revised Roman rite, since it incorporated this central convergence between the interpretation of celestial phenomena above Rome and the subterranean past beneath the city's topography.

\section{References}

Albericius, Raymundus. 1759-1770. Venerabilis Caesaris Baronii S. R. E. Cardinalis Bibliothecarii Epistolae et Opuscula. 3 vols. Rome.

Bailey, Gauvin Alexander. 2009. Between Renaissance and Baroque: Jesuit Art in Rome, 15651610. Toronto: University of Toronto Press.

Baldini, Ugo. 2001. The Roman Inquisition's Condemnation of Astrology in the 16th Century; Antecedents, Reasons and Consequences. In Church, Censorship and Culture in Early Modern Italy, ed. Gigliola Fragnito and trans. Adrian Belton, 79-110. Cambridge: Cambridge University Press.

Baronius, Caesar. 1740. Apparatus in Annales Ecclesiasticos Caesaris Baronii, cum critice pagii \& notis. Lucca. 
Benedetti, Sandro. 1973. Giacomo del Duca e l'architettura del Cinquecento. Rome: Officina. Benedetti, Sandro, and Giuseppe Zander, eds. 1990. L'arte in Rome nel secolo XVI. Vol. 1: L'architettura. Bologna: Cappelli.

Boncompagni, Ludovisi, and Paolo Francesco. 1998. La famiglia Boncompagni: tra Bologna e Roma. In Incunaboli e cinquecentine della biblioteca di Gregorio XIII Boncompagni: Dal Collegio Germanico alla Pontificia Università Lateranense, ed. Luigi Falcone, 14-18. Milano: Mursia.

Cheney, Iris. 1989. The Galleria delle Carte Geografiche at the Vatican and the Roman Church's View of the History of Christianity. Renaissance Papers: 21-37.

Ciappi, Marc' Antonio. 1596. Compendio delle heroiche et cloriose attioni et santa vita di papa Gregorio XIII. Rome.

Clavius, Christoph. 1601. In Sphaeram Ioannis de Sacro Bosco commentarius. Venice.

Danti, Ignazio. 1577. Le scienze matematiche ridotte in tavole. Bologna.

. 1583. Le due regole della prospettiva pratica di M. Iacomo Barozzi da Vignola con $i$ comentarij del R. P. M. Egnatio Danti dell' ordine de Predicatori, Matematico dello Studio di Bologna. Rome.

Doni, Anton Francesco. 1562. Espositione del Doni sopra del XIII cap. dell'Apocalisse. Padova.

Fagiolo, M., and M. Luisa Madonna. 1972. La Roma di Pio IV: La Civitas Pia, la Salus Medica, la Custodia Angelica. Parte I: il programma. Arte illustrata 51: 383-402.

1973. La Roma di Pio IV: Parte II: il sistema dei centri direzionali e la rifondazione della città. Arte illustrata 54: 186-212.

Fiorani, Francesca. 2005. The Marvel of Maps: Art, Cartography, and Politics in Renaissance Italy. New Haven: Yale University Press.

Firpo, Massimo. 1991. The Cardinal. In Renaissance Characters. Ed. Eugenio Garin and Trans. Lydia G. Cochrane, 46-97. Chicago, University Press.

Fontaine, Jacques. 1997. Priszillian, Priszillianisten. Theologische Realenzyklopädie (TRE) XXVII: 449-454.

Frabricii, Principio. 1588. Delle allusioni, imprese, et emblemi del sig. Principio Frabricii sopra la vita, opere, et attioni di Gregorio XIII, pontefice Massimo. Rome.

Guazzelli, Giuseppe A. 2005. Cesare Baronio e il Martyrologium Romanum: problemi interpretativi e linee evolutive di un rapporto diacronico. In Nun alia tempora, alii mores: Storici e stoia in età posttridentina, ed. Massimo Firpo, 47-89. Florence: Olschki.

King, John N. 1989. Tudor Royal Iconography: Literature and Art in an Age of Religious Crisis. Princeton: Princeton University Press.

Lippincot, K. 1990. Two Astrological Ceilings Reconsidered: The Sala di Galatea in the Villa Farnesina and the Sala del Mappamondo at Caprarola. Journal of the Warburg and Courtauld Institutes 53: 185-207.

Malesevic, Filip. 2015. Kardinal Caesar Baronius: Kirchenhistorik und Kunstpatronage im posttridentinischen Zeitalter der Päpste. Saarbrücken: AV Akademikerverlag GmbH \& Co..

Marinig, L. 1999. Due disegni di Lorenzo Sabatini per gli affreschi della sala Bologna in Vaticano. In Scritti di storia dell'arte in onore di Jürgen Winkelmann, ed. S. Béguin, M. Di Giampaolo, and P. Narcisi, 185-195. Naples: Paparo.

McCuaig, William. 1989. Carlo Sigonio: The Changing World of the Late Renaissance. Princeton: Princeton University Press.

Millanesi, Marcia. 1994. Geography and Cosmography in Italy from XV to XVII Century. Memorie della società astronomica Italiana 65: 443-468.

Noreen, Kirstin. 1998. Ecclesiae militantis triumphi: Jesuit Iconography and the CounterReformation. Sixteenth Century Journal 29: 689-715.

Olmi, Giuseppe. 1992. L'inventario del mondo: catalogazione della natura e luoghi del sapere nella prima età moderna. Bologna: Società editrice il Mulino.

Ostrow, Steven F. 1996. Art and Spirituality in Counter-Reformation Rome: The Sistine and Pauline Chapels in S. Maria Maggiore. Cambridge: Cambridge University Press. 
Paleotti, Gabriele. 2012. Discourse on Sacred and Profane Images. Trans. William McCuaig. Los Angeles: Getty Research Institute.

Partridge, Loren. 1995. The Room of Maps at Caprarola, 1573-75. The Art Bulletin 77: 413-444. Pastor, Ludwig von Olmütz. 1930. The History of the Popes from the Close of the Middle Ages. Vol. 19. London: Trubner.

Pisanelli, Baldassare. 1575. Discorso sopra il dragone di fuoco apparso in Roma, l'anno 1575. Bologna.

. 1582. Discorso sopra la cometa che apparve in Roma alli XI maggio 1582. Bologna.

Praz, M. 1971. Il concetto di emblematica e le sue manifestazioni nel Rinascimento e nell' età barocca. Emblemi e Insegne 4: 794-799.

Prodi, Paolo. 1964. San Carlo Borromeo e il Cardinale Gabriele Paleotti: due vescovi della Riforma Cattolica. Critica storica 3: 135-151.

- 2005. Vecchi appunti e nuove riflessioni su Carlo Sigonio. In Nun alia tempora, alii mores: Storici e stoia in età posttridentina, ed. Massimo Firpo, 291-310. Florence: Olschki.

Prosperi, Simonetta, and Valenti Rodinò, eds. 2007. I disegni del Codice Resta di Palermo. Milan: Silvana.

Quinlan-McGarth, M. 1997. Caprarola's Sala della Cosmografia. Renaissance Quarterly 50: 1045-1100.

Reusch, Franz Heinrich. 1967. Der Index der verbotenen Bücher: Ein Beitrag zur Kirchen- und Literaturgeschichte. 3 vols. Bonn: Aalen Scientia-Verlag.

Rocca, Angelo. 1578. Discorso filosofico et teologico intorno alle comete ove si scoprono molti secreti della natura, con la dichiaratione de' miracoli, et portenti occorsi al mondo. Venice.

Ruffini, Marco. 2005. Le imprese del drago: Poilitica, emblematica e scienze naturali alla corte di Gregorio XIII (1572-1585). Rome: Bulzoni.

— 2012. Un drago per il papa: Emblematica e politica alla corte di Gregorio XIII. In Unità e fammenti di modernità: Arte e scienza nella Roma di Gregorio XIII Boncompagni (15721585), ed. Claudia Cieri Via, Ingrid D. Rowland, and Marco Ruffini, 113-130. Pisa: F. Serra.

Schiffmann, René. 1985. Roma felix: Aspekte der städtebaulichen Gestaltung Roms unter Sixtus $V$. Bern: Peter Lang AG.

Schütte, Margret. 1993. Die Galleria delle Carte Geografiche im Vatikan: Eine ikonologische Betrachtung des Gewölbeprogramms. Hildesheim: Olms.

Scribner, Robert W. 1981. For the Sake of the Folk: Popular Propaganda for the German Reformation. Cambridge: University Press.

Soldi, Manlio and Roberto Fusco, eds. 2005. Martyrologium Romanum: Ad novam Kalendarij rationem, \& Ecclesiasticae historiae veritatem restitutum (1584). In Monumenta Liturgica Concilii Tridentini. Vol. 2. Vatican City: Libreria editrice vaticana.

Soldi, Manlio and Achille Maria Triacca, eds. 2012. Breviarum Romanum: Editio princeps (1568). In Monumenta liturgica Concilii Tridentini. Vol. 3. Vatican City: Libreria editrice vaticana.

Tarde, Jean. 1984. A la rencontre de Galilée: Deux voyages en Italie. Ed. Francois Moureau and Marcel Tetel. Geneva: Slatkine

Tomassetti, Luigi, ed. 1857-1872. Bullarium diplomatum et privilegiorum St. Romanorum pontificum Tauriensis editio. 24 vols. Turin.

Urban, Emily. 2011. La volta celeste dell Sala Bologna e la tradizione della cosmografia rinascimentale. In La Sala Bologna nei Palazzi Vaticani: Architettura, cartografia e potere nell'età di Gregorio XIII, ed. Francesco Ceccarelli and Nadja Aksamija, 57-64. Venice: Marsilio.

Watt, Tessa. 1991. Cheap Print and Popular Piety 1550-1564. Cambridge: University Press.

Watts, Pauline M. 2004. The Donation of Constantine, Cartography, and Papal Plenitudo Potestatis in the Sixteenth Century: A Paper for Salvatore Camporeale. Modern Language Notes 119: 88-107.

Ziggelaar, A. 1983. The Papal Bull of 1582 Promulgating a Reform of the Calendar. In Gregorian Reform of the Calendar: Proceedings of the Vatican Conference to Commemorate its 400th Anniversary, 1582-1982, ed. G.V. Coyne, M.A. Hoskin, and O. Pedersen, 201-239. Vatican City: Pontificia Academia Scientiarum. 